ORNL/CON-463

OAK RIDGE

NATIONAL

LABORATORY

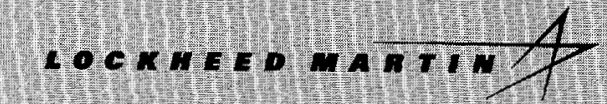

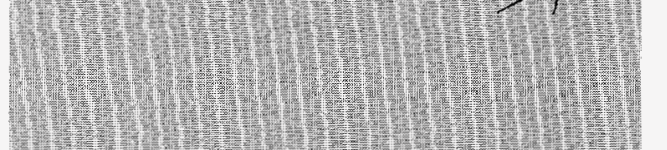

14)

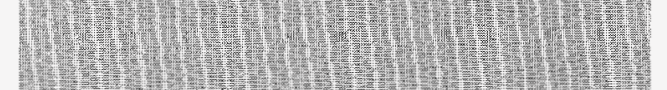

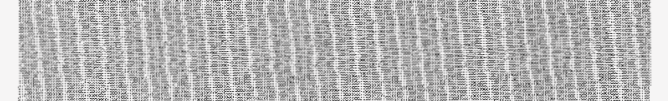
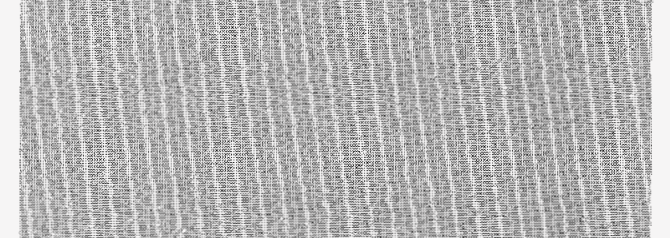

.t.

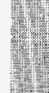

\title{
The Impact of Carbon Taxes or Allowances on the Electric Generation Market in the Ohio and ECAR Region
}

\author{
Stanton W. Hadley
}

$$
\begin{aligned}
& \text { RECEIVED } \\
& \text { AUG } 171998 \\
& \text { OSTI }
\end{aligned}
$$

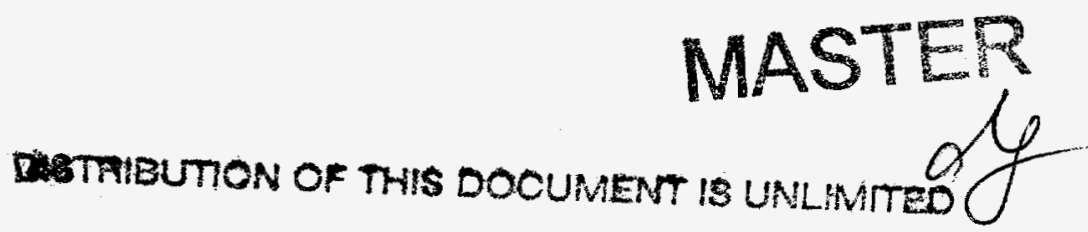


This report has been reproduced clirectly from the best available copy.

Available to DOE and DOE contractors from the Office of Scientific and Technical Information, P.O. Box 62, Oak Ridge. TN 37831; prices available from (423) 576-8401, FTS 626-8401.

This report was prepared as an account of work sponsored by an agency of the United States Government. Neither the United States Government nor any agency thereof, nor any of their employees, makes any warranty, express or implied, or assumes any legal liability or responsibility for the accuracy, completeness, or usefulness of any information. apparatus, product, or process disclosed, or represents that its use would not infringe privately owned rights. Reference herein to any specific commercial product, process, or service by trade name, trademark, manufacturer, or otherwise, does not necessarily constitute or imply its endorsement, recommendation, or favoring by the United States Government or any agency thereof. The views and opinions of authors expressed herein do not necessarily state or reflect those of the United States Government or any agency thereof. 


\section{DISCLAIMER}

Portions of this document may be illegible in electronic image products. Images are produced from the best available original document. 


\title{
ENERGY DIVISION
}

THE IMPACT OF CARBON TAXES OR ALLOWANCES ON THE ELECTRIC GENERATION MARKET IN THE OHIO AND ECAR REGION

\author{
STANTON W. HADLEY
}

\begin{abstract}
JULY 1998
Sponsored by

Office of Policy Development

U.S. Environmental Protection Agency
\end{abstract}

OAK RIDGE NATIONAL LABORATORY

Oak Ridge, Tennessee 37831 managed by

LOCKHEED MARTIN ENERGY RESEARCH CORP.

for

U.S. DEPARTMENT OF ENERGY

under contract No. DE-AC05-96OR22464 

LIST OF FIGURES $\ldots \ldots \ldots \ldots \ldots \ldots \ldots \ldots \ldots \ldots \ldots \ldots \ldots \ldots \ldots \ldots$

LIST OF TABLES $\ldots \ldots \ldots \ldots \ldots \ldots \ldots \ldots \ldots \ldots \ldots \ldots \ldots \ldots \ldots \ldots \ldots \ldots$

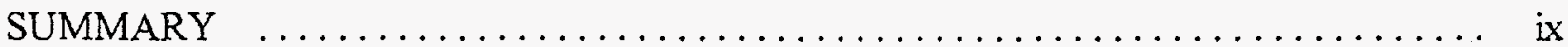

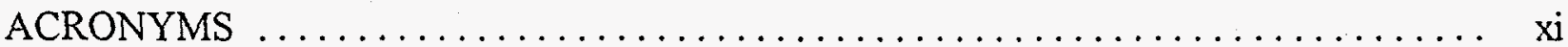

1. INTRODUCTION $\ldots \ldots \ldots \ldots \ldots \ldots \ldots \ldots \ldots \ldots \ldots \ldots \ldots \ldots \ldots \ldots \ldots$

2. CARBON EMISSION REDUCTION POLICIES $\ldots \ldots \ldots \ldots \ldots \ldots \ldots \ldots \ldots \ldots \ldots$

METHODS FOR CONTROLLING EMISSIONS $\ldots \ldots \ldots \ldots \ldots \ldots \ldots \ldots \ldots$

THE IMPACT OF RESTRUCTURING $\ldots \ldots \ldots \ldots \ldots \ldots \ldots \ldots \ldots \ldots$

3. ANALYTICAL BACKGROUND $\ldots \ldots \ldots \ldots \ldots \ldots \ldots \ldots \ldots \ldots \ldots \ldots \ldots$

THE COMPUTER MODEL $\quad \ldots \ldots \ldots \ldots \ldots \ldots \ldots \ldots \ldots \ldots \ldots \ldots \ldots \ldots \ldots$

ENTERING DATA FOR THE OHIO AND ECAR REGION $\ldots \ldots \ldots \ldots \ldots \ldots$

THE BASE CASE $\ldots \ldots \ldots \ldots \ldots \ldots \ldots \ldots \ldots \ldots \ldots \ldots \ldots \ldots \ldots$

4. IMPACTS OF CARBON CHARGES $\ldots \ldots \ldots \ldots \ldots \ldots \ldots \ldots \ldots \ldots \ldots \ldots \ldots$

CARBON REDUCTION SUPPLY CURVE $\ldots \ldots \ldots \ldots \ldots \ldots \ldots \ldots \ldots \ldots \ldots \ldots$

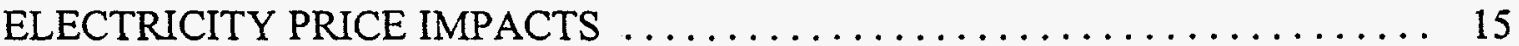

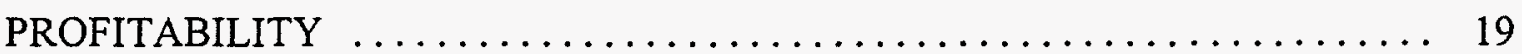

IMPACT OF SUPPLY VERSUS DEMAND $\ldots \ldots \ldots \ldots \ldots \ldots \ldots \ldots \ldots \ldots$

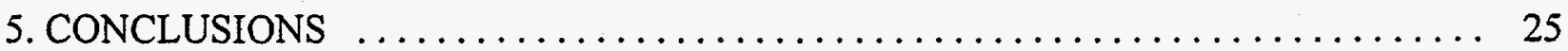

ACKNOWLEDGMENTS $\ldots \ldots \ldots \ldots \ldots \ldots \ldots \ldots \ldots \ldots \ldots \ldots \ldots \ldots \ldots \ldots$

REFERENCES $\ldots \ldots \ldots \ldots \ldots \ldots \ldots \ldots \ldots \ldots \ldots \ldots \ldots \ldots \ldots \ldots \ldots \ldots \ldots \ldots$ 



\section{LIST OF FIGURES}

S-1. Percentage reductions in carbon emissions before and after the demand reduction (also shown) due to price elasticity. ................

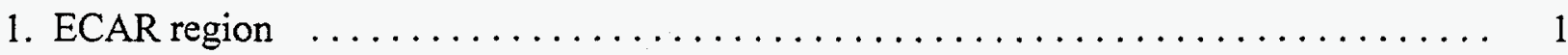

2. Cost of existing coal plant and new gas combined cycle plant operating at $90 \%$ capacity factor with and without a carbon charge.

3. Separation of 131 Ohio power plants into 25 bins by technology and variable

4. Peak period load duration curves and prices before and after elasticity.

5. Supply curve for carbon reductions in ECAR as a function of carbon tax rate or allowance price.

6. Average spot price used to adjust LDC and final price for generation .

7. Carbon reductions and electricity demand reductions as a function of carbon charge rates.

8. ECAR capacity (GW) with carbon charge and demand reduced due to price elasticity.

9. ECAR generation (GW-year) with carbon charge and demand reduced due to price elasticity.

10. Average total cost and market price at different charge rates.

11. Higher carbon reduction at low carbon charges with demand held constant than if demand reduced due to price elasticity.

12. ECAR capacity (GW) with varying carbon charge rates and constant demands.

13. ECAR generation (GW-year) with varying carbon charge rates and constant demands. 
14. Changes in key parameters with carbon charges of $\$ 25 / \mathrm{tC}, \$ 50 / \mathrm{tC}$, and $\$ 75 / \mathrm{tC}, \ldots \ldots 25$ 


\section{LIST OF TABLES}

1. Electric generating capacity by fuel type for $1995 \ldots \ldots \ldots \ldots \ldots \ldots \ldots$

2. Variable costs to producers with tax or allowance trading. $\ldots \ldots \ldots \ldots \ldots \ldots$

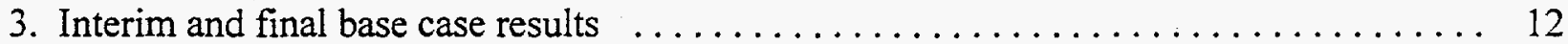

4. Carbon savings from the base case of $137 \mathrm{MtC}$ with both supply and demand changing and with just supply changing. ................. 20

5. Capacity and generation by technology for $\$ 25 / \mathrm{tC}$ charge cases, with and without elasticity effect 



\section{SUMMARY}

In recent international negotiations, the United States proposed reducing greenhouse gas emissions to below 1990 levels by 2012. To do this, the electricity sector will need to lower its carbon emissions significantly. Different regions of the country will face varying impacts from these reductions depending on their current generation resources and the costs of implementation.

This study analyzes the East Central Area Reliability Coordination Agreement (ECAR) region because of its reliance on coal-fired generation. The study begins with a general discussion of the different methods proposed to reduce emissions in the electricity sector. Potential methods include a carbon tax or a carbon emission cap with trading of allowances. Trading of allowances can be expanded beyond the electricity sector or even beyond national boundaries.

Carbon reduction policies that incorporate the cost of emissions in the variable cost of electricity (such as carbon taxes and caps with emissions trading) have an impact both on the day-to-day operations of existing power plants and the choice of technology for new plants. While in implementation the two policies are very different, their impact on generation would be the same. Given a price of $\$ X /$ ton of carbon, a reduction of $\mathrm{Y}$ tons would result, and vice versa. However, risk, uncertainty, and policy objectives will influence what type of controls, if any, are established.

To quantify the impacts of these methods we used the Oak Ridge Competitive Electricity Dispatch (ORCED) computer model. Concentrating on the ECAR region and Ohio, we established a base set of generating plants and electricity demands for the year 2010. ORCED then modified the capacities of new and existing plants to minimize the overall cost of generation in the region. From the calculated real-time prices we changed the electricity demands using assumed price elasticities and let ORCED again change capacities to minimize costs. The resulting base case changed the mixture of technologies by eliminating the construction of new coal plants, combined cycle (CC) plants, and combustion turbine (CT) plants except for those planned to meet near-term demands. The model also retired one nuclear plant.

We then introduced a carbon charge (either an allowance price or carbon tax) at various prices per metric ton of carbon $(\$ / \mathrm{tC})$. By comparing the amount of carbon reduction to the carbon charge we generated a supply curve of carbon reductions (Figure $\mathrm{S}-1$ ).

Below a carbon charge of $\$ 40 / \mathrm{tC}$, the carbon reductions are about the same as the reductions in electricity demand. With price elasticity, an increase in price reduces demand. Coal-fired production drops, lowering the carbon emissions. Above $\$ 40 / \mathrm{tC}$, new plants begin to displace some of the least efficient coal and oil plants, and a nuclear plant is not retired, as in the base case. Above $\$ 50 / \mathrm{tC}, \mathrm{CC}$ plants begin to displace coal production, accelerating the carbon reduction. In the $\$ 75 / \mathrm{tC}$ case, coal represents $60 \%$ of production, versus $90 \%$ in the base case. 


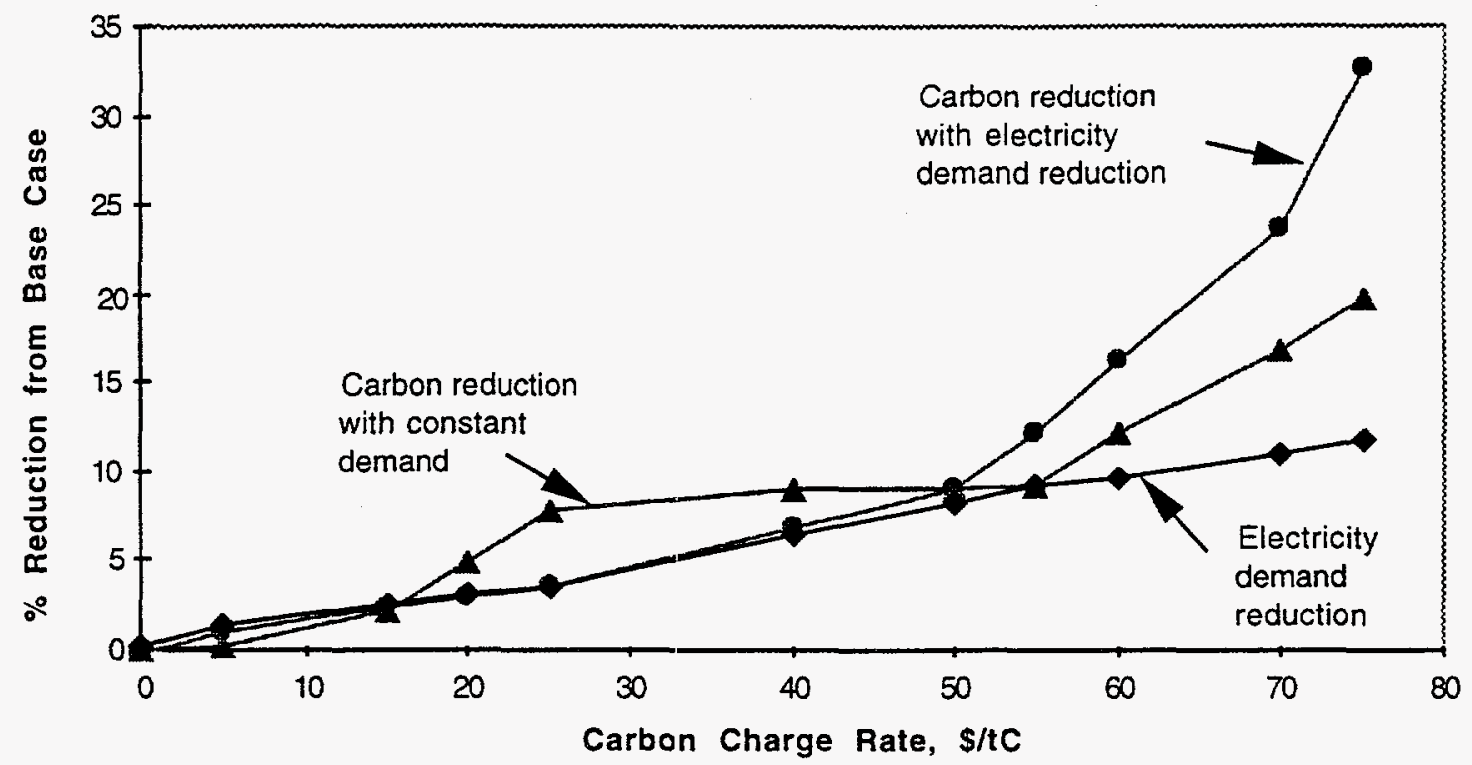

Figure S-1. Percentage reductions in carbon emissions before and after the demand reduction (also shown) due to price elasticity.

The marginal-cost-based prices for generation increase from $3.0 \mathrm{k} / \mathrm{kWh}$ in the base case to $3.9 \mathrm{k} / \mathrm{kWh}$ with a carbon charge of $\$ 75 / \mathrm{tC}$. Because of this increase, total demand declines $11 \%$. Peak demands decline $10 \%$ (or $19 \%$ from the original peak before price elasticity changes the load shape). There is more carbon reduction at low charge rates if demands are kept constant than if demand is reduced. This is because with the original demands over $9 \mathrm{GW}$ of CT capacity is built. At carbon charge rates between $\$ 10$ and $\$ 40 / \mathrm{tC}$ these are replaced by new CC plants, reducing carbon emissions.

Profitability for generators declines with increased carbon charges, largely because of the reduced demand from higher prices, creating a larger reserve margin. High peak prices, which are a large source of the profitability of plants in a marginal-cost-based pricing system, are not available as much of the time. Also, at higher carbon charge levels, new CC plants are built to displace less efficient coal plants. The capital costs of these plants are not reflected in their variable costs so are not as easily collected through marginal-cost pricing.

For the Ohio utilities, the most prominent result is the cancellation of planned coal and CC plants and the retirement of the Perry nuclear plant in the base case. Under the base case with no demand change, additional CT plants are built, but with demand adjustments due to price elasticity, these plants are less needed. When charge rates approach $\$ 40 / \mathrm{tC}$, the Perry plant becomes economical to run. The first coal plant to be replaced is the Mansfield plant, when charge rates exceed $\$ 50 / \mathrm{tC}$. Operating cost data for all plants were based on an average of their 1993-1995 performance. If significant improvements are made in their operating characteristics, the pattern of cancellations, retirements, and new construction will be different. 


\section{ACRONYMS}

CC combined cycle

CT combustion turbine

ECAR East Central Area Reliability Coordination Agreement

EIA Energy Information Administration

LDC load duration curve

$\mathrm{MtC}$ million metric tons of carbon

NEMS National Energy Modeling System

NERC North American Electric Reliability Council

$O \& M \quad$ operations and maintenance

ORCED Oak Ridge Competitive Electricity Dispatch model

PUCO Public Utility Commission of Ohio

RDI Resource Data International

ST steam powered

tC metric tons of carbon 


\section{INTRODUCTION}

Recent discussions in Kyoto among representatives of nations around the world have resulted in a pledge by the U.S. administration to reduce greenhouse gas emissions to below 1990 amounts by 2008 to 2012. The major greenhouse gas emitted, at least in volume, is carbon dioxide. And one of the major emitters of $\mathrm{CO}_{2}$ is electricity generation, especially from coal but also from other fossil fuels.

Several mechanisms to reduce carbon emissions have been proposed. Currently under way are voluntary reductions made under the auspices of the Climate Challenge program run by the U.S. Department of Energy. Achieving more dramatic reductions will require programs that directly influence how the electric system will be run. Examples of such policies are a cap that allows trading of emission allowances or a tax on carbon emissions.

The North American electricity grid is separated into 11 regional reliability councils, collectively called the North American Electric Reliability Council (NERC). The East Central Area Reliability Coordination Agreement (ECAR) is the reliability council that covers Ohio and Indiana, along with parts of Kentucky, Illinois, Maryland, Michigan, Pennsylvania, Virginia, and West Virginia, as shown in the accompanying map (Figure 1).

Ohio and the rest of the ECAR region rely more heavily

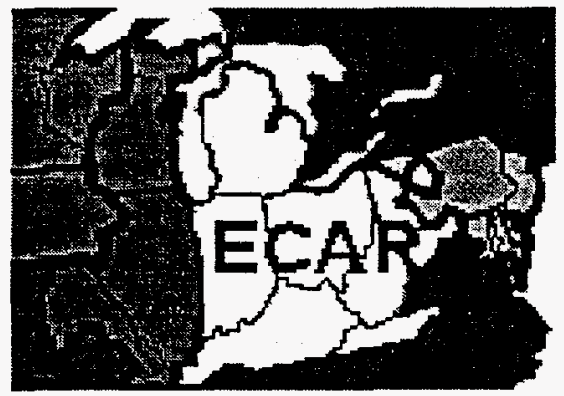

Figure 1. ECAR region on coal-fired generation than any other U.S. region. Currently, $86 \%$ of Ohio's generation capacity uses coal, and for ECAR as a whole it is $82 \%$ (Table 1). This compares to a national proportion of $51 \%$.

The Public Utilities Commission of Ohio (PUCO) has raised a concern on the impacts of carbon limitations on Ohio's electric system. How much could prices rise in response to changes? What mechanisms for reduction are available and how do they differ? What changes will be felt by the local generating companies, fuel suppliers, and customers? We were interested in the ECAR region because of its

Table 1. Electric generating capacity by fuel type for 1995a

\begin{tabular}{|l|c|c|c|}
\hline \hline Source & Ohio & ECAR & National \\
\hline Coal & $86 \%$ & $82 \%$ & $51 \%$ \\
Gas & $3 \%$ & $7 \%$ & $20 \%$ \\
Nuclear & $8 \%$ & $7 \%$ & $16 \%$ \\
Oil & $2 \%$ & $3 \%$ & $8 \%$ \\
Hydro & $0 \%$ & $1 \%$ & $5 \%$ \\
Other & $0 \%$ & $0 \%$ & $0 \%$ \\
\hline
\end{tabular}

a Source: RDI 1997. 
heavy reliance on coal. As the most heavily coal-dependent region in the country, it would be most affected by carbon reduction policies.

The electric industry is changing. In the past, the industry has largely been vertically integrated, with a single company owning the generation, transmission, and distribution facilities needed to serve the customers in a specific franchise territory. Prices were regulated and set to match the average cost of providing service. The industry was seen as a natural monopoly with little competition between suppliers.

These days the generation market is in the process of being separated from the transmission and distribution functions and becoming a competitive market. Instead of being based on the average cost of service, prices for generation will be based on the marginal cost of service. Other services, such as firm capacity and ancillary services, may be separately priced and marketed. The other electric industry functions-transmission and distribution-will continue to be regulated and priced as before.

In the face of these changes, carbon reduction policies will have different effects than under the previous, regulated system. The price from the marginal cost of production may change more or less than an average-based price under different policies, and the price, in turn, may change the customer demand for power. States will have less control over the types of plants built or retired. Individual plants, instead of the utility as a whole, will be required to show profits. All these factors change the impact of carbon reduction policies.

The purpose of this report is to study the effect of carbon reduction policies on the cost and price of generation in the ECAR region, with an emphasis on Ohio. In order to do that, we modeled the possible electric generation system for the ECAR and Ohio region for the year 2010 using a model developed at Oak Ridge National Laboratory called the Oak Ridge Competitive Electric Dispatch model (ORCED). We let the model optimize the system based on various factors and carbon reduction policies to understand their impact. We then used the electricity prices and assumed demand elasticities to change the demands while also requiring all power plants to be profitable.

The next chapter discusses the different potential policies for carbon reduction and issues involving a restructured market. Chapter 3 clescribes the model used for this analysis, the ECAR electricity sector, and the establishment of a base case. The fourth chapter describes the results of applying various carbon emission reduction approaches to the region. Our conclusions are in chapter 5 . 


\section{CARBON EMISSION REDUCTION POLICIES}

Many actions have been proposed to reduce the emissions of greenhouse gases. Technological development can increase the availability of more efficient technologies. Public education can lead people to choose less polluting activities and lifestyles. Regulations can force reductions through enforcement and penalties. The most effective means for reducing emissions will probably be economic in nature. It will have to cost more to release than to not release greenhouse gases for reductions to occur on a wide scale.

In the electric generation market there are already technologies available with low or zero emissions. Renewable energy sources, advanced coal technologies, and nuclear power are all available but usually at an overall cost (construction plus operation) higher than the current market will support. Only high-efficiency gas combustion turbine (CT) and gas combined-cycle (CC) plants are both relatively low-carbon emitting and economic in today's market.

\section{METHODS FOR CONTROLLING EMISSIONS}

Currently, there is no limit or cost imposed on carbon emissions in electric generation. Any cost to society from their release is external to the direct cost seen by the generators and customers. In economic terms, carbon emissions are an externality that is borne by those not necessarily buying or selling the product. Society generally has two mechanisms to pass these external costs back to the producer-in other words, to internalize them. One method is to regulate their release; the other is to tax the release. In the first method, the cost to the producer is defined by the cost of changing the producer's practices to meet the regulated limits. The regulation may be in the form of type of technology used in the process or limits on the amount of emission. The regulations can be placed on individual generators, all generators owned by a single company, or all generators in a region, where the region can be subnational, national, or supernational. If limits are not placed at the producer or plant level, allowance trading can occur while the total remains under the overall limit. Producers may be allowed to trade the allowances among themselves so that they minimize their total cost.

In the second method, an extra charge is placed on the pollutant as a fee or tax. The charge raises the direct cost, and the producers, to minimize their cost, change their practices. They may choose to pay the charge on their emission or implement changes that reduce their charge, whichever is most cost effective.

Emission limits with trading and carbon taxes have essentially the same effect on the costs of electricity production. With limits and trading, a market-based price for allowances will develop. If the tax and allowance price are the same, a producer's direct variable costs are the same with carbon taxes or allowance trading, as shown in Table 2. With taxes, a producer's variable cost of production is the sum of its fuel cost, any variable operation and maintenance (O\&M) cost, and 
the cost of the tax based on the carbon emitted. With allowance trading a producer's variable cost is the sum of its fuel cost, variable O\&M cost, and the purchase of allowances based on the carbon emitted. If the producer already owns sufficient allowances, then the cost is not what it takes to buy them but rather the foregone revenue from not being able to sell them. If a producer prices electricity on the basis of marginal cost, then bid prices should be about the same under each system.

While both mechanisms may cost about the same to a producer given perfect information, real world considerations will strongly influence any actual policy approach. Relative uncertainty about the marginal cost of damage and the marginal cost of reduction of greenhouse gases lends weight to arguments favoring using a tax instead of a limit. Also, producers would prefer the stability of a known cost of emissions rather than face the risks that allowance prices could be much different than expected. However, since the ultimate policy goal is a reduction of greenhouse gases, a cap gives a more direct measure of success. Further discussion on the relative efficiencies of various policies can be found in Leary and Scheraga (1994) as well as elsewhere in the current economics literature.

Klein et al. state in their 1993 paper that carbon taxes and carbon limits do not have the same effect (Klein et al. 1993). Their analysis is based on a utility that sets prices on the basis of its average cost, as occurs under current regulations. In that case, a limit would raise average costs only by the amount needed to purchase allowances or to change operations to stay under the limits. A carbon tax would raise the average cost much more because of the required payment of the tax on all carbon emissions. Consequently, a carbon limit would have less impact on prices, and therefore less impact on demand-side reductions due to higher prices. However, since our study uses marginal-cost pricing instead of average-cost pricing, the allowance price or tax would effectively raise the price to consumers by the same amount.

An older form of controls, used in some acid rain control regulations, was the requirement or banning of certain technologies, rather than (or as well as) controls on the emissions themselves. If regulations are placed on the type of technology or fuel used, then trading cannot take place. For example, if the government mandates gas combustion instead of coal combustion, or requires the retirement of high-emission plants, those plants in violation will have no option but to modify their operations or shut down. This approach may not be the most cost-effective solution compared to other options. 


\section{THE IMPACT OF RESTRUCTURING}

The electricity market is currently moving towards a competitive generation market that is separate from the transmission and distribution functions. Much has been written about the ways and means of moving to this market and the changes that are involved. One impact will be that prices for electricity generation will shift from an average-cost basis to a marginal-cost basis. Power plants will bid into the spot market generally on the basis of their variable cost of production, and the market-clearing price at any time will be the bid price of the most expensive plant operating. The final market will actually be more complicated than this, involving firm contracts, futures markets, hedging, capacity payments, and other factors involved with a large commodity market, but the key change will be frequently varying prices based on the marginal cost.

The addition of a carbon charge will change the order by which plants will be selected for operation. (We will use the term "charge" to refer to either a carbon tax or the price of emission allowances.) For example, Figure 2 shows the cost of power from a typical existing coal plant and a new gas CC plant, both running at a $90 \%$ capacity factor. If both bid into the market at their variable cost, the coal plant would be selected first. Not until the lower-cost coal plant's capacity was exhausted would the gas $\mathrm{CC}$ plant enter the market. Depending on the local demand and supply situation, the gas CC plant may run at a lower capacity factor than the $90 \%$ shown, raising its fixed costs higher and making it more difficult for the plant to remain profitable. Both plants would need to recoup their fixed costs through higher energy prices when demand brings on more expensive plants and raises the market clearing price, through sale of firm capacity, or through sale of ancillary services.

With a $\$ 50 / \mathrm{tC}$ charge, the relative price position of each plant reverses. The gas $\mathrm{CC}$ plant would be called upon a higher percentage of the time. It also would be more likely to be profitable, since when the existing coal plant is called upon, its price will reflect the high cost of its carbon emissions. Because the $\mathrm{CC}$ plant would not have as high a carbon penalty, it could use the higher prices to contribute to its capital costs or profits.

A key factor on the impact of the reduction policy is whether the cost to comply is a variable cost or fixed cost. Variable costs tied to production (such as a $\$ / \mathrm{tC}$ charge) are reflected in the prices that each generator would bid into a spot market. This raises the real-time price which the market will see and respond to. Fixed costs are less easily captured in the price and so will have less influence on demands. 


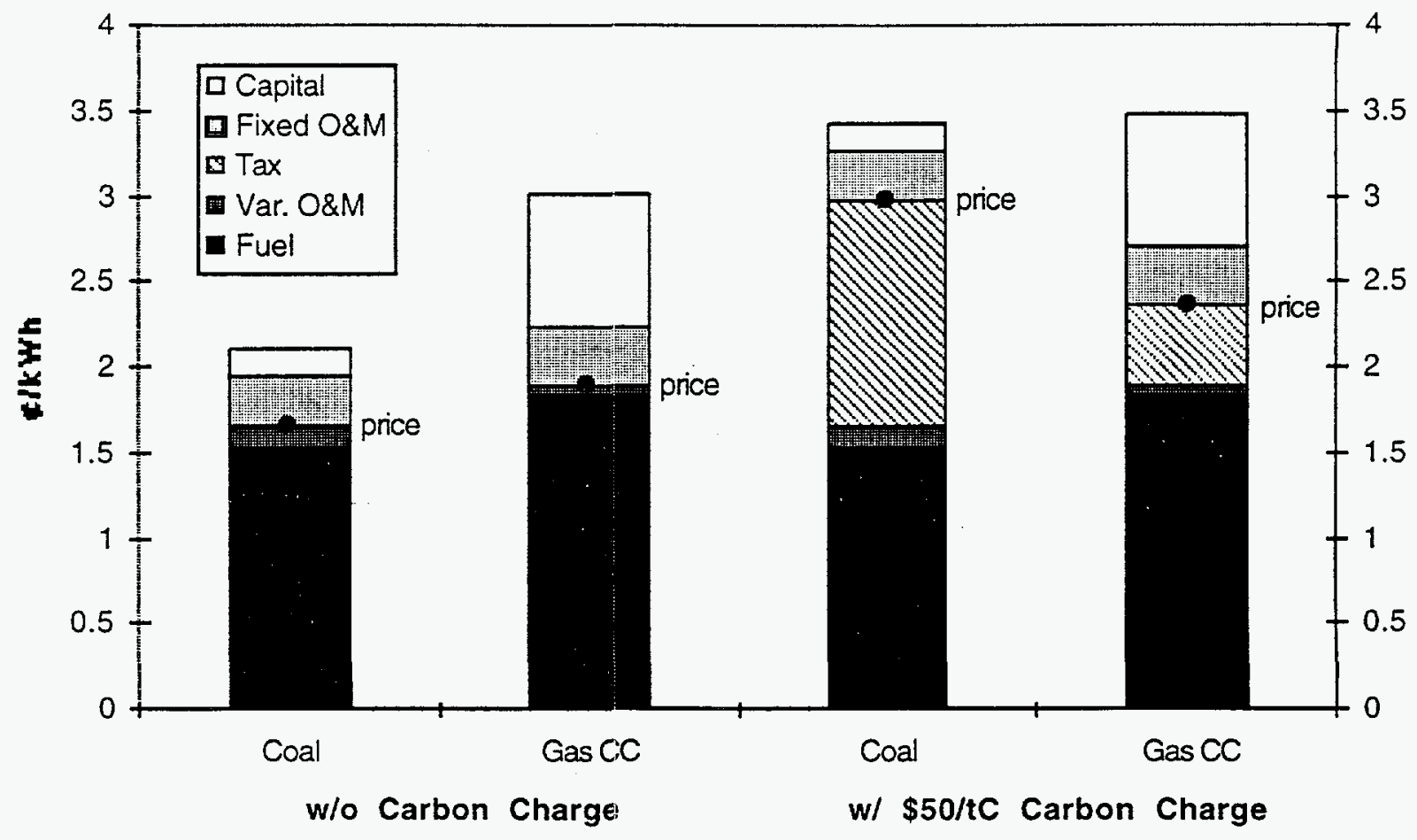

Figure 2. Cost of existing coal plant and new gas combined cycle plant operating at $90 \%$ capacity factor with and without a carbon charge. Note that a plant's bid price is based on its variable cost. 


\section{ANALYTICAL BACKGROUND}

\section{THE COMPUTER MODEL}

As noted in the Introduction, we used a new model developed at Oak Ridge National Laboratory to conduct this analysis. The ORCED model, developed primarily with support from the U.S. Environmental Protection Agency, was used in the recent study on carbon reductions by five national laboratories (Interlaboratory Working Group 1997). Two versions of the model were used in this study. One version dispatches generation (the output available from 26 power plants) to meet loads in two regions for a particular year, 2010 in this analysis. The two regions are connected by a single transmission link that is characterized by its capacity (MW), costs $(\notin / \mathrm{kWh})$, and losses (percentage of throughput). The loads in each region are represented by loadduration curves for two seasons each year. The second version combines the two regions into a single region of 51 plants, ignoring transmission constraints. This version is more suitable for optimization runs because it avoids the sequential nature of dispatching for each region prior to bulk-power trading. Our report ORCED: Simulating the Operations and Costs of Bulk-Power Markets (Hadley and Hirst 1998) gives additional detail on the structure and operation of ORCED.

Although this spreadsheet model is a simple one, it captures the key features of the U.S. electricity system as it might function with competitive bulk-power markets. In particular, generating units bid their variable costs (the sum of fuel costs plus variable O\&M costs) into a market; the market selects the cheapest units to meet demand for each point in time. All generators are paid the same price during each time period, the price bid by the highest-cost unit then operating. For the two-region version, the markets in the two regions interact during each time period such that the output from units in the low-cost region are increased and the output from units in the high-cost region are decreased until an equilibrium is reached. This equilibrium is determined by the transmission capacity, costs, and losses between the two regions as well as by the generating units on-line and customer loads in the two regions. If the transmission capacity between the two regions is infinite and if transmission costs and losses are zero, then the two regions operate as one, and hourly spot prices are the same in both regions.

Although less detailed, the structure of our model is similar to the National Energy Modeling System (NEMS) model used by the Energy Information Administration (EIA) in its analysis of the effects of competition on retail electricity prices (EIA 1997). Both models determine timevarying competitive prices primarily on the basis of the variable cost of the most expensive generator running at that time. (EIA includes certain administrative and general costs as well as taxes in its definition of "variable" costs; we exclude these costs and taxes.) Both models explicitly account for the effects of reliability on prices, especially during those few hours a year 
when available supplies are not enough to meet unconstrained demand. And both models treat consumer responses to changes in overall and real-time (i.e., spot) electricity prices.

\section{ENTERING DATA FOR THE OHIO ANI ECAR REGION}

As shown in the map in Figure 1, all of Ohio is within ECAR. In segregating the demands and capacities available to Ohio, as opposed to the rest of ECAR, we had two choices. We could select on the basis of where the generating plants were located, or we could select based on the location of the utility that owned the plant. We chose the latter. This means that plants located outside of Ohio could have some of their capacity assigned to Ohio, based on the fraction of ownership by an Ohio utility.

Because the electric industry is regulated, utilities must report much of the operating and financial data with regards to their generating plants. (This is likely to diminish in a competitive market.) This information is provided to state and federal regulatory bodies, reliability councils, and industry trade groups. Resource Data International (RDI 1997) compiles and publishes much of this data in a form that is easily searchable by parameters such as NERC region, owner, and fuel type. We used this database to select data for 1993 to 1995 for all powerplants in ECAR. These data were then separated into the two groups-Ohio and the rest of ECAR.

EIA maintains separate databases that include planned facilities (EIA 1996b), although the data associated with them is less complete than RDI's. The plants that are expected to be added between now and 2010 according to EIA were added to the listings. For the various parameters that were missing, representative values used by EIA in the Annual Energy Outlook 1997 (EIA 1996a) were assigned to these new plants. PUCO has a separate list of expected additions and retirements expected between now and 2010 within Ohio (Lambeck 1997). Modifications were made using this list as well.

We next had to separate the plants for each region (131 for Ohio and 293 for the rest of ECAR) into the 26 bins available for each within ORCED. Some of these 131 and 293 plants represent portions of a single plant owned by different utilities. First, we sorted the list by fuel type and technology used. Within each major group, we ranked the plants based on their variable cost (fuel plus variable O\&M). Tentative bin assignments were made, and the resulting combined capacities, variable costs, total costs, capacity factors, and ages were checked. Figure 3 shows the variable cost, total cost, and combined capacity for the 131 plants assigned to Ohio. A similar graph was created for the rest of ECAR.

The most important factor considered during binning was similarity in variable costs, since dispatching is done on the basis of variable cost. Also, relative similarity in the combined capacities between bins was important. Total capacity of a bin that is greatly higher than the others may distort the results of probabilistic outages; greatly lower capacity "wastes" a bin, forcing extra consolidations in the remaining ones. 


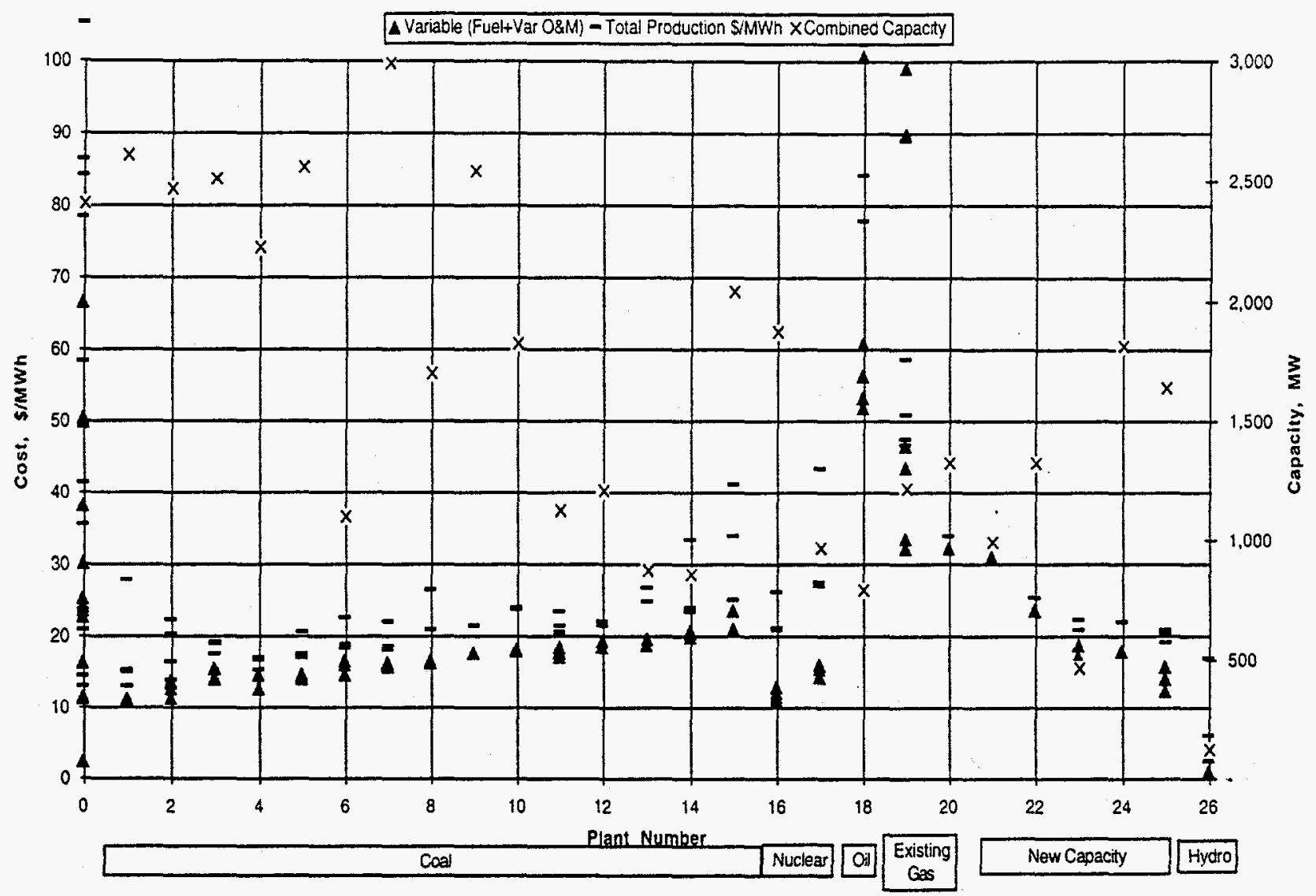

Figure 3. Separation of 131 Ohio power plants into 25 bins by technology and variable cost for use in ORCED.

Once all plants were assigned to a bin (with the "zero" bin being used for retired plants or plants with insufficient data), the weighted average cost and operating parameters were determined. These became the plant-specific inputs for ORCED.

Annual capital costs for the plants were calculated in two different ways, depending on whether the plant is already built or only planned. For existing plants, construction cost (based on a weighted average of the plants in the bin) and average year of construction were entered in the model. ORCED calculated the actual depreciation, interest, allowed return on equity, and taxes for 2010 based on these costs and dates. (ORCED makes an adjustment to the construction date to compensate for additional capital costs post-construction.) Since these costs are sunk, they do not enter into the objective function for optimizing avoidable costs. For new plants, we went one step further by calculating an annualized charge that gives the same net present value as the schedule of depreciation, return, etc., for that plant. These costs are avoidable and so are included when trying to minimize avoidable costs.

The RDI database also includes the hour-by-hour demands for the major utilities within ECAR. The 1995 demands were split into two seasons: a peak season from June 1 to August 31 and an off-peak season for the remaining nine months. For each season the total hourly demands 
on the ECAR system were sorted by increasing size. A three-segment load duration curve (LDC) was then fit to each season's data. A similar set of curves are calculated using just the Ohio utilities.

Next, the expected peaks for the two regions needed to be found. In a report on the long-term forecast of energy requirements (Feyzioglu 1997a and 1997b), PUCO reports a peak demand in 1995 of $29,785 \mathrm{MW}$ and predicts a demand of $34,726 \mathrm{MW}$ for Ohio in 2010. According to RDI data, the ECAR coincident peak for 1995 was $89,869 \mathrm{MW}$. If we assume that ECAR demands grow at the same rate as Ohio, the peak for the entire ECAR region will be 104,777 MW in 2010. This represents an annual growth rate of slightly over $1 \%$.

\section{THE BASE CASE}

Once all parameters were set for each region, ORCED was run. Based on the expected additions and retirements in capacity, and the growth in demand, the reserve margin (the amount of excess capacity as a percentage of peak demand) for Ohio will be $18.5 \%$, but for the rest of ECAR it will be $-1.9 \%$ in 2010 . Combined, the reserve margin is $4.9 \%$. This implies a significant amount of trading between Ohio and the rest of ECAR. The transmission links between the two have about $6000 \mathrm{MW}$ of capacity (Lambeck 1997). When running the two-region version of ORCED, we found that this was sufficient; maximum capacity sales between them during any period was $5130 \mathrm{MW}$. (One limitation with ORCED is that interregion sales are underestimated because of the separate dispatching for each region using their load duration curves. Opportunities for sales because of forced outages and/or greatly differing demands at a given time are not captured.)

Since transmission constraints appeared not to be a crucial problem, we chose to use a oneregion version of ORCED that contained the same plants as the two-region version. It modeled 51 plants-25 for Ohio, 25 for the rest of ECAR, and one energy-limited hydro plant that combined the hydro capacities of both regions. This was done because the optimization and runtime of a single region version was better and faster. Also, if there are no transmission constraints, the one-region version models the electric system more accurately.

Once the expected demands and capacities for 2010 were put in ORCED, we could let the model change various parameters to optimize the electric system relative to a given objective function. For this analysis we chose to minimize the overall avoidable costs for the system. PUCO asked us to use a base case reserve margin of 6\%. We let ORCED manipulate the capacities of all of the plants, with a stipulation that the reserve margin equal $6 \%$. Constraints were set so that existing plants could only be retired, not increased in capacity. New plants could have their capacities set anywhere from zero to roughly $9000 \mathrm{MW}$. This limit was set to prevent one plant within ORCED from becoming too high a proportion of the total capacity. Since there were multiple new plants with similar characteristics, this was not a limiting factor.

Once we had a reasonable real-time price curve based on optimizing capacity to meet the base demand, we could model the impact of these prices on demand levels. We first assumed that the 
original load duration curves based on today's set of demands reflect customer responses to time-invariant prices. This is consistent with PUCO's long-range forecast (Feyzioglu 1996a). The load factor was held constant into the future, meaning that peaks were not modified by real-time prices. We did not adjust the overall demand levels, since the PUCO documentation admits that prices will be higher in the future to reflect the cost of new capacity. Instead, we just manipulated the relative shape of the curve based on real-time prices vs a static price (Figure 4). We added in a price of $3.2 \phi / \mathrm{kWh}$ for transmission, distribution, and customer service. This did not change between cases and mainly served to temper the elasticity impact of changes in generation prices.

As shown in Figure 4, the effect of real-time prices is to flatten the load duration curve, especially around the peak region. We assumed an elasticity of -0.1 for the real-time price difference from the average. For later cases involving carbon charges we added an elasticity of -0.5 that applied to changes in the average price from the base case average price. Figure 4 shows the LDC and prices for the base case before and after demand elasticities are applied. Total demand (the area under the LDC) does not change by more than $0.5 \%$ in this case, but the peak drops by $9 \%$. The off-peak season has a similar set of curves.

Consumers and utilities have had very little experience with real-time pricing to date. Therefore, considerable uncertainty surrounds estimates of consumer response to such time-varying prices (Faruqui et al. 1991; EIA 1997). The estimate of -0.5 represents the longterm elasticity as average prices increase or decrease over the years. The elasticity of -0.1 represents short-term, intra-period responses. Customers are likely to be less responsive to temporary price increases from factors such as weather-related events so have a lower elasticity.

Following the change in the $L D C$, if we reoptimize the case to minimize avoidable cost, less capacity is needed. The amount available is reduced until a balance is reached between the cost of building a plant and the cost of the unserved energy due to lack of capacity. When we allowed the reserve margin to vary, in the base case the optimum reserve margin remained around $6 \%$. 
In addition to minimizing avoidable costs, we added the constraint that all plants must be profitable (or nearly so.) This better simulates the real-world situation. We allowed a small $(<\$ 5 / \mathrm{kW}$-year) loss to recognize that there may be other sources of revenue for plants, or that they may have expectations of profitability in later years. Further iterations of applying the elasticity to the derived price curve would make further changes to the LDC, but we did not perform these iterations. The new base case has total carbon emissions of 137.2 million metric tons (MtC) , $0.2 \%$ higher than the previous base.

The results for the base cases are shown in Table 3. Column 2 shows the results if supply and demands are not changed from what was found in the original data sources above. The third column shows the case if we keep demand fixed (zero elasticity) but allow the generating plant

Table 3. Interim and final base case results

\begin{tabular}{|c|c|c|c|}
\hline \multirow[b]{2}{*}{ Parameter } & \multirow[b]{2}{*}{$\begin{array}{l}\text { Original Supply } \\
\text { and Demand }\end{array}$} & \multicolumn{2}{|c|}{ Optimized Cases } \\
\hline & & $\begin{array}{l}\text { Only Supply } \\
\text { Changed }\end{array}$ & $\begin{array}{c}\text { Supply and } \\
\text { Demand Changed }\end{array}$ \\
\hline Energy market price $(\phi / \mathrm{kWh})$ & 2.30 & 2.41 & 2.99 \\
\hline Capacity price $(\$ / k W y r)$ & $268.9^{\mathrm{a}}$ & 53.0 & 1.2 \\
\hline Combined price $(\boldsymbol{k} / \mathrm{kWh})$ & 6.58 & 3.27 & 3.01 \\
\hline Average total cost $(\boldsymbol{k} / \mathrm{kWh})$ & 2.43 & 2.37 & 2.29 \\
\hline Peak demand (MW) & 104,777 & 104,777 & 95,215 \\
\hline Energy demand (GWh) & 582,989 & 582,989 & 581,758 \\
\hline Reserve margin (\%) & $4.9 \% \mathrm{~b}$ & $6.0 \%$ & $6.0 \%$ \\
\hline Carbon emissions $(\mathrm{MtC})$ & 133.6 & 136.9 & 137.2 \\
\hline \multicolumn{4}{|l|}{ Capacity by source (MW) } \\
\hline Nuclear & 7,696 & 6,729 & 6,729 \\
\hline Coal & 84,997 & 83,353 & 82,535 \\
\hline Oil & 2,433 & 2,433 & 2,433 \\
\hline Gas-CT & 8,124 & 14,498 & 5,180 \\
\hline Gas-CC & 2,581 & 0 & 0 \\
\hline Gas-Steam & 3,295 & 3,295 & 3,295 \\
\hline Hydro & 756 & 756 & 756 \\
\hline Total & 109,882 & 111,064 & 100,928 \\
\hline
\end{tabular}

a The high capacity price is due to the high construction cost of a new coal plant requiring a capacity charge for cost recovery. The optimized cases do not build this plant.

b The original case includes only known existing and planned plants. Other plants would be built to increase reserve margin. 
capacities to vary. For the last column, our final base case, we used the real-time prices from the supply-only case and allowed demand elasticity to change the load shape.

In the data for each of these cases, we first show the average energy-only (spot market) price and the capacity price needed so that all plants, even the worst operating, would recover at least their avoidable costs. The combined price is the energy price plus the capacity price converted to cents per kilowatt-hour of sales. The average total cost is the sum of the variable, fixed, and capital costs (including a reasonable return on equity) divided by sales. This is equivalent to the average-cost based price that a regulated industry would charge.

Because the combined market price is higher than the average-cost-based price, most generators are making profits above the formerly regulated rate of return. This is especially true in the original supply and demand case because the new coal plant requires a very high capacity charge to pay for its avoidable fixed and variable costs. Plants not yet built have their capital cost included in the avoidable cost, since the cost can be avoided by not building the plant. The capacity charge in the case where only supplies changed is approximately the fixed cost of a new CT. In fact, the plant that defines the $\$ 53$ capacity charge is CT capacity built in 2001 , with an annualized capital charge of $\$ 48 / \mathrm{kW}$-year and fixed O\&M of $\$ 12 / \mathrm{kW}$-year. Extra revenue from energy sales offsets $\$ 7 / \mathrm{kW}$-year of the capital cost. In the fourth column of Table 3, with supply and demand levels changed, the demand load factor is higher, so all but the most expensive coal plant recover all of their avoidable costs.

The extra profits show that by the year 2010, the ECAR region will have enough plants with low capital costs (largely depreciated plants) that their profits on marginal-based price sales will more than cover the fixed costs of all plants. The total revenue in the base case (the case with both supply and demand changed) is $\$ 17.3$ billion, while total costs (including the current allowed return on equity) are $\$ 13.2$ billion, leaving profits above current returns of $\$ 4.1$ billion. This does not include increased economic efficiency due to competition. As the electricity market increases competition between plants, their owners will work to reduce the O\&M costs and improve the efficiency and availability of their plants. To some extent this will result in lower prices so that the consumers will reap the benefits, but also the plants that are most successful at improving operations will increase their profitability.

With optimization, some of the more expensive plants, from an avoidable cost basis, are either retired or not built in the first place. The Perry nuclear plant is retired, and new coal and CC plants are not built. Instead, gas CT capacity is increased if demand is kept constant. The lower capital and fixed O\&M costs of this technology make it a better fit in the overall combination of plants, despite its higher energy cost. With lower demands, even CT capacity is reduced from the original planning base. The energy-only price increases in the optimized case because the plants retired or not built generally had low variable costs, which translates into lower spot prices. The overall (energy plus capacity) price declines, however. 



\section{IMPACTS OF CARBON CHARGES}

What are the changes to the ECAR and Ohio electric systems from various carbon emission policies? How much reduction will be due to decreases in customer demand as opposed to changes in supply-side operations? Given a base case with no carbon reduction policies in place, we can institute a carbon charge of varying amounts to see what changes occur in prices, demand, and supply.

Other regions of the country, or other countries, will have different supply curves for carbon reduction. Given a carbon charge rate, they may reduce their emissions more than ECAR, or conversely, if a limit is set (e.g., a 7\% reduction), they may reduce their emissions more and sell the allowances to ECAR. Since we are not measuring the supply curve for other regions, we cannot say what the price of allowances will be for a given limit if trading is allowed with those regions. Our carbon reductions are a function of the price. The price is a function of the reductions only if there is no trading with other regions.

\section{CARBON REDUCTION SUPPLY CURVE}

To determine the supply curve of carbon reductions for the ECAR region we must set up cases depicting the ECAR market with different carbon charge rates. As with the base case, the process must be done in two parts. First, ORCED optimized the capacities using the original demands but with a carbon charge imposed. From this, a tentative market price curve was established that included the impact of the carbon charge. Demands were then adjusted on the basis of the new price curve, and an ORCED optimization was run again.

The results of the analysis are shown in Figure 5. Given a carbon charge of $\$ 25 / \mathrm{tC}$, there is a $3.6 \%$ reduction in carbon emissions from the 2010 base case. At $\$ 50 / \mathrm{tC}$ the reduction is $9.1 \%$. The reductions then increase rapidly; at $\$ 75 / \mathrm{tC}$ the reductions are over $32 \%$ of the emissions in the base case. Savings would continue to increase at higher allowance prices, both because of higher electricity prices and the replacement of coal technology with CC plants. Savings could continue to increase, either through further substitution of coal with gas-fired capacity or through construction of non-carbon-emitting capacity, although at higher prices.

\section{ELECTRICITY PRICE IMPACTS}

Several factors interact to give the results in Figure 5. First, let us consider the impact of price changes and consequent demand changes. As the charge increases, the market price also increases, and so demand is reduced due to price elasticity. Figure 6 shows the average of the spot market prices used to adjust the LDC curves for each case and the average price from the final cases at each carbon charge. The real-time prices vary over the year; the plot just shows the average value for a whole year. 


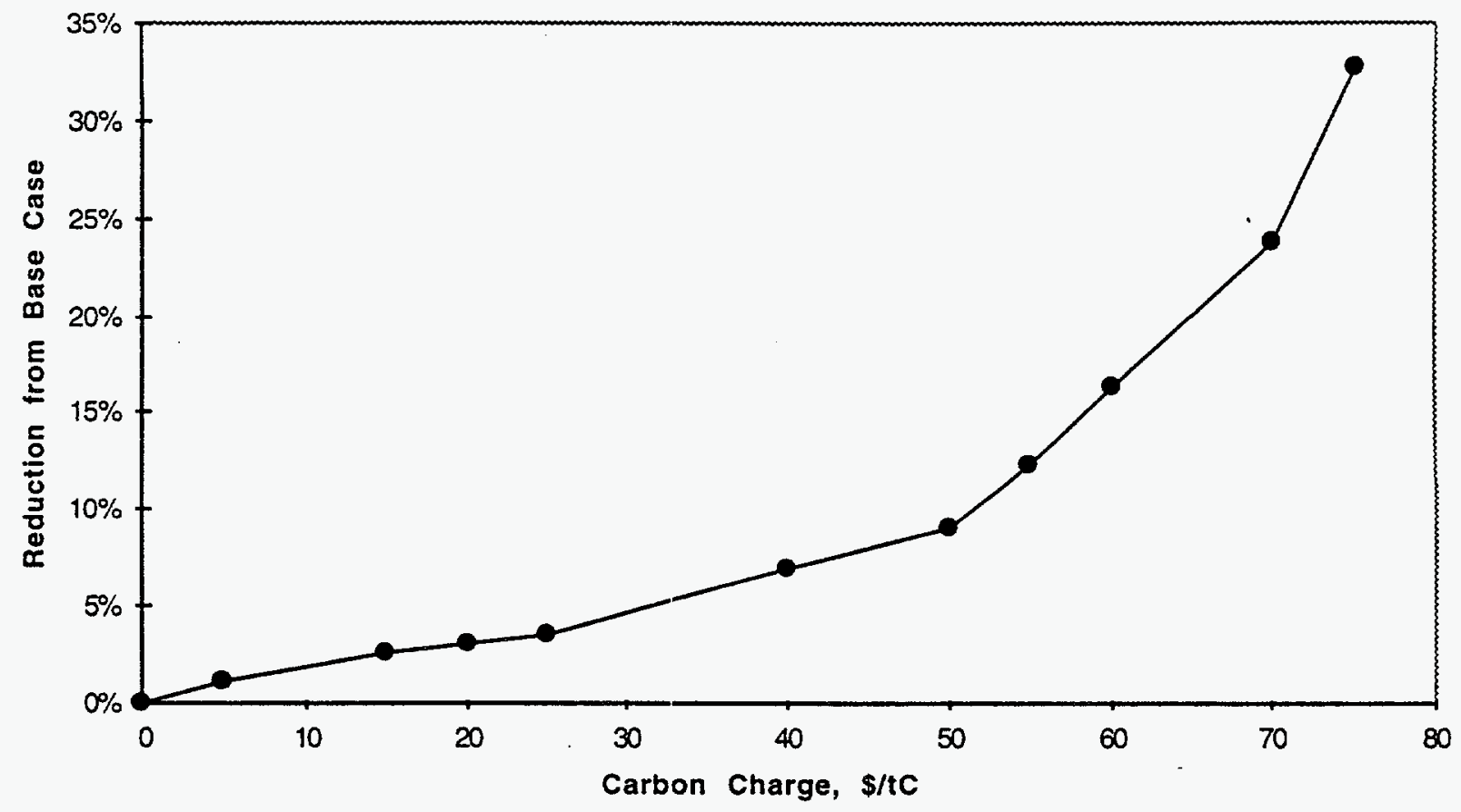

Figure 5. Supply curve for carbon reductions in ECAR as a function of carbon tax rate or allowance price.

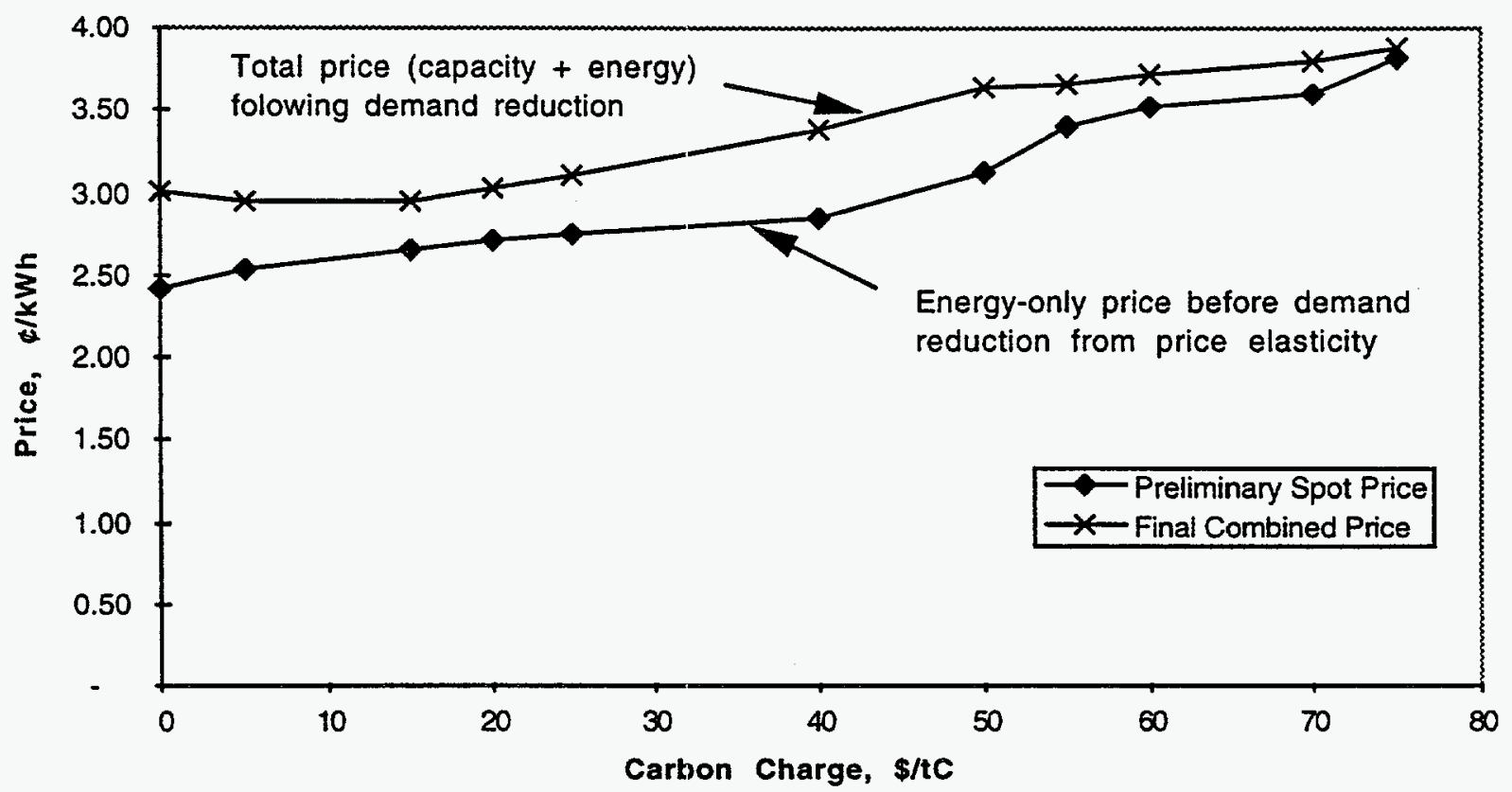

Figure 6. Average spot price used to adjust LDC and final price for generation . 
The price to consumers increases from $3.0 \notin / \mathrm{kWh}$ to $3.9 \mathrm{~d} / \mathrm{kWh}$ when carbon charges go from zero to $\$ 75 / \mathrm{tC}$. If an extra $3.2 \phi / \mathrm{kWh}$ is added to represent the nongeneration costs of electricity, the retail price increases $15 \%$, from $6.2 \phi / \mathrm{kWh}$ to $7.1 \phi / \mathrm{kWh}$.

This price increase reduces demand (and consequent carbon emissions) because of elasticity. If the percentage reduction in energy is compared to the percentage reduction in carbon emissions, it is apparent that at low carbon charge rates, below $\$ 40 / \mathrm{tC}$, the two are essentially the same (Figure 7). At $\$ 40 / \mathrm{tC}$ they start to separate as some of the least efficient coal and oil plants are retired. At $\$ 55 / \mathrm{tC}$ the Perry nuclear plant is no longer retired and new CC plants are added, further displacing coal plants. As the charge increases, $\mathrm{CC}$ plants become more economical and are added to the mix. While some coal plants are retired, some are kept but run at a lower capacity factor.

At the higher carbon charge rates, the low-carbon technologies accelerate the carbon reductions beyond that just from demand reductions. Figures 8 and 9 show the capacity and generation mix for each of these cases. Note that coal plants provide $82 \%$ of capacity and $90 \%$ of generation in the base case, but that this declines to $60 \%$ of capacity and $59 \%$ of generation at a carbon charge of $\$ 75 / \mathrm{tC}$. In the base case, demands are met by existing plants. As the charge rate increases, demand declines, but it is not expensive to maintain the existing plants. This causes the reserve margin to increase from $6.0 \%$ in the base case to $8.2 \%$ at $\$ 25 / \mathrm{tC}$ to $12.6 \%$ in the $\$ 75 / \mathrm{tC}$ case.

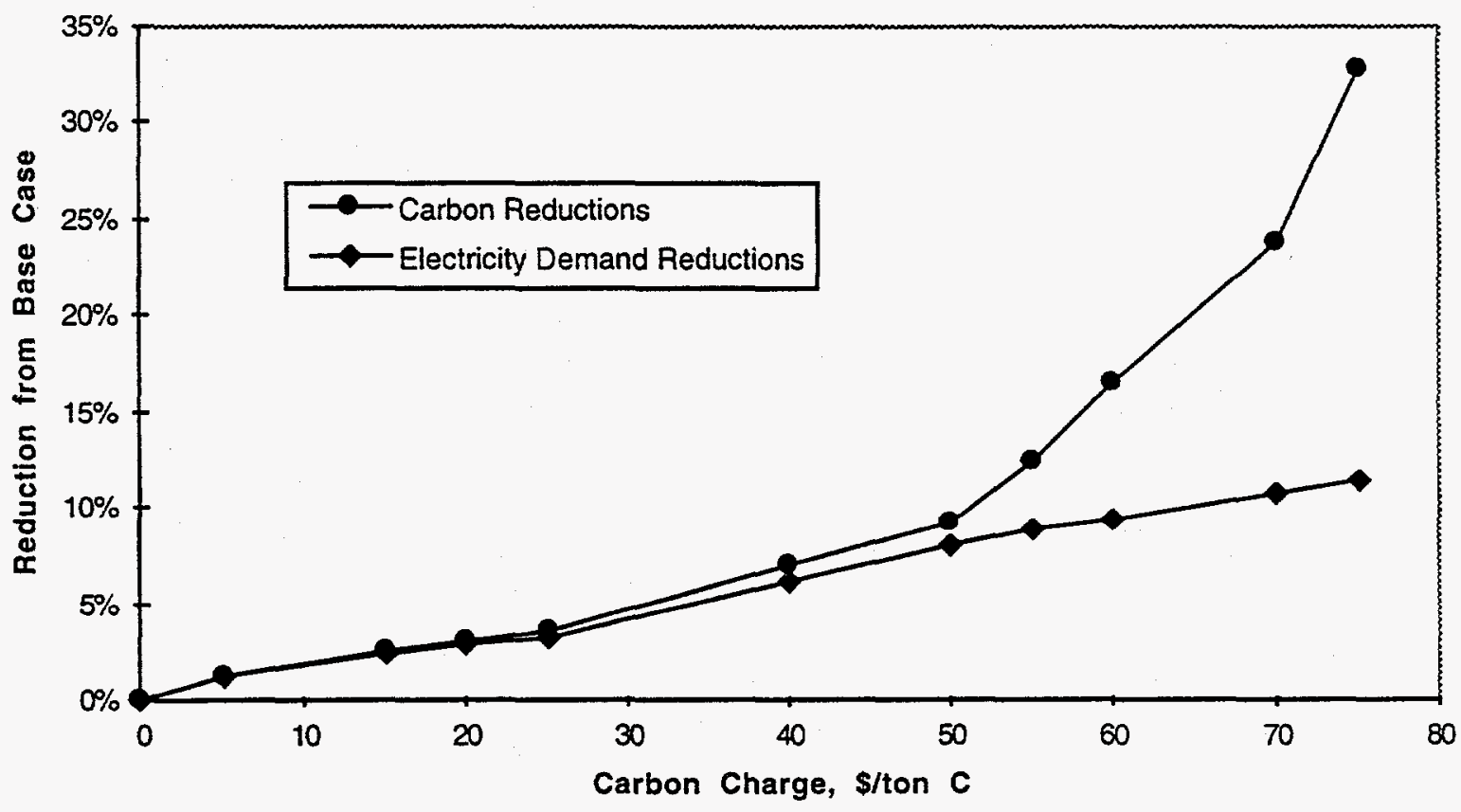

Figure 7. Carbon reductions and electricity demand reductions as a function of carbon charge rates. 


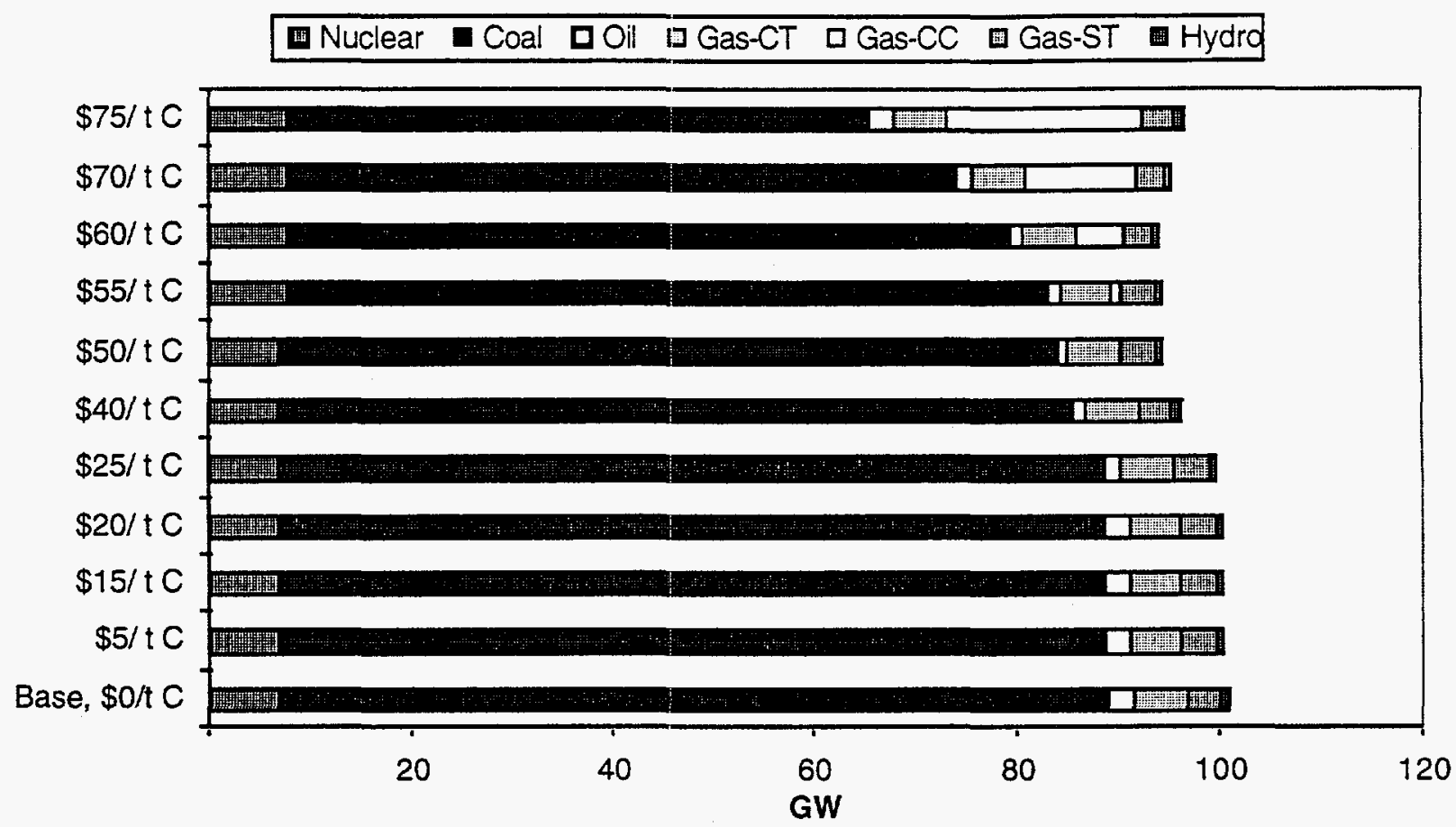

Figure 8. ECAR capacity (GW) with carbon charge and demand reduced due to price elasticity.

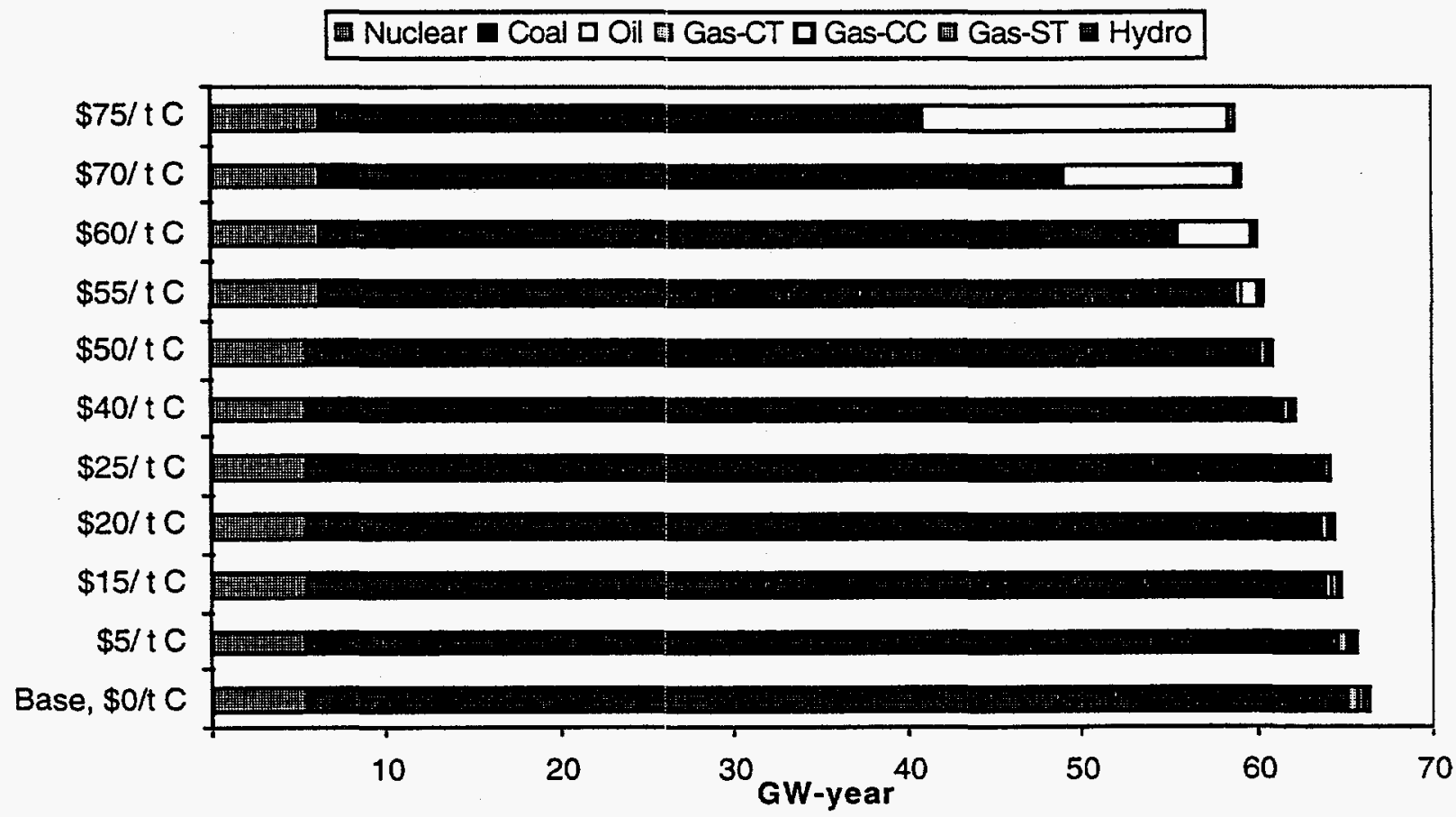

Figure 9. ECAR generation (GW-year) with carbon charge and demand reduced due to price elasticity. 


\section{PROFITABILITY}

Profitability declines as the carbon charge increases. In the base case the plants as a whole have significant earnings over and above their total cost, equaling $0.7 \% / \mathrm{kWh}$ (Figure 10.) As the reserve margins increase in the higher carbon charge cases, the high cost plants are not called upon as much and do not set the market price for as much of the time. In addition, ORCED calculates a price to charge during times of unserved energy due to the combination of forced outages and high demand. This price is around $24 \mathrm{c} / \mathrm{kWh}$ in these cases and is paid to all suppliers during the period of unserved energy. At the higher reserve margins, the percentage of time this price is available is less. Consequently, plants do not receive as much of a bonus from high prices and their profitability declines. Profitability is also hurt when new plants are built. New plants are not built until the charge rate reaches $\$ 55 / \mathrm{tC}$, at which point $\mathrm{CC}$ plants are added to the mix. Once they are added, their low variable operating costs cause the flattening of the price curve. Since total cost continues to increase with the charge rate (both from higher payments on carbon emissions and capital costs of new plants), the market price eventually drops below the average total cost. So with increased carbon charges, the profitability of generators declines.

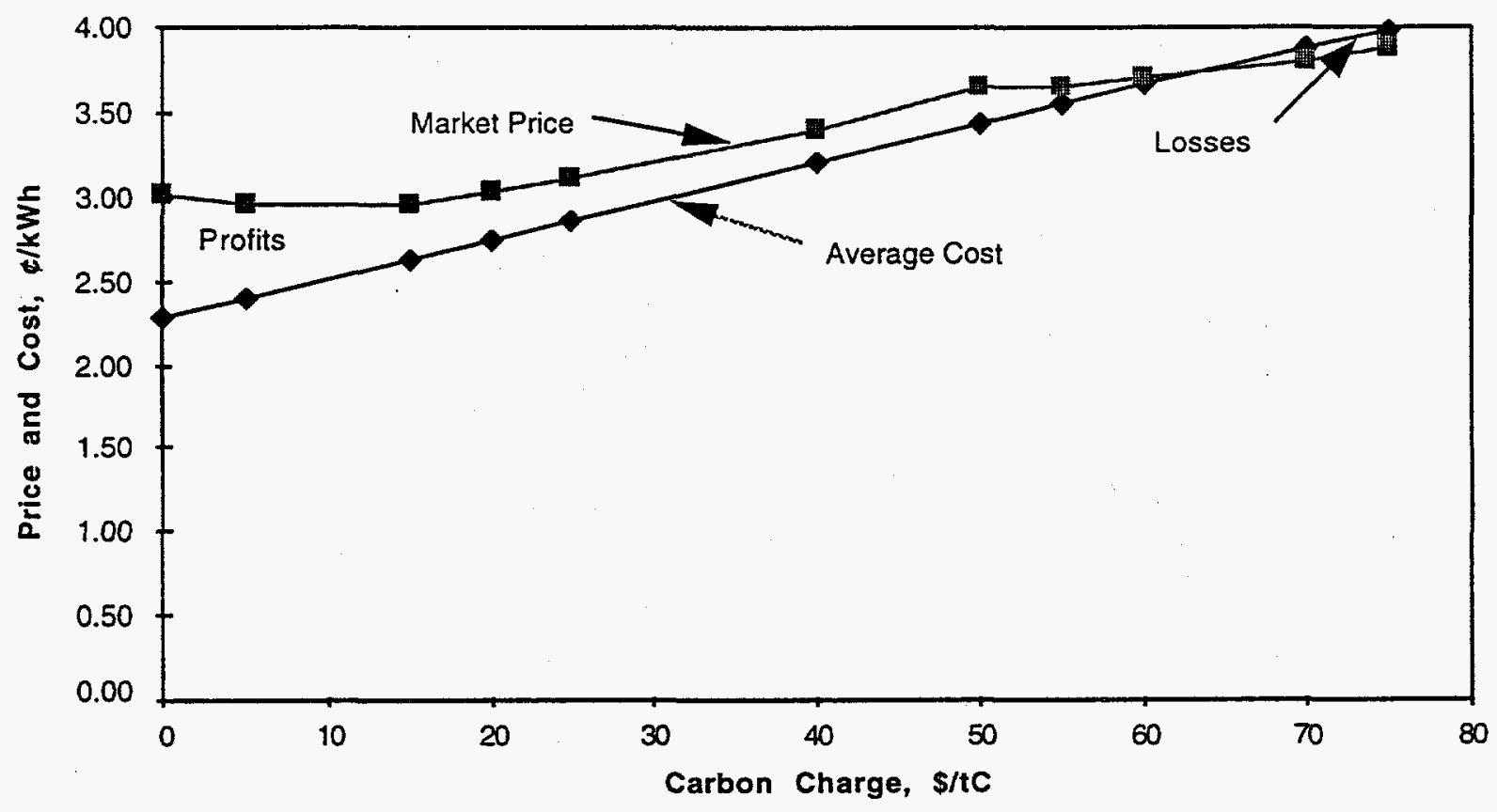

Figure 10. Average total cost and market price at different charge rates. The area between the curves represent extra profits to the generators. 


\section{IMPACT OF SUPPLY VERSUS DEMAND}

How much of the savings are due to reduction in demand, and how much are due to changes in supply? In order to develop our final cases we had to run each case with our initial set of demands. This allowed us to compare the anount of carbon reduction if only generation supplies were allowed to change. The difference in carbon reductions between these cases and the final cases show the effect of reducing demand.

The most interesting result was that at carbon charges below $\$ 50 / \mathrm{tC}$, keeping demand constant gave higher carbon reductions than if demand was reduced (Table 4 and Figure 11). Because of the higher peak demands in the original data set, ORCED brought on additional capacity. At low carbon charge rates, ORCED chose to bring on CC plants instead of new CT plants. Because the $\mathrm{CC}$ plants were baseload plants, they displaced generation from coal plants as well as the CT capacity. This reduced carbon emissions greatly, even at relatively low charge rates. So even though carbon reductions basically tracked electricity reductions (as shown in Figure 7), demand reduction due to carbon charges and consequent price increases actually had a negative impact on how much carbon could be reduced.

Table 4. Carbon savings from the base case of $137 \mathrm{MtC}$ with both supply and demand changing and with just supply changing. Difference can be attributed to changes in demand.

\begin{tabular}{|c|ccc|}
\hline $\begin{array}{c}\text { Carbon Charge } \\
\text { \$/tC }\end{array}$ & $\begin{array}{c}\text { Only Supply } \\
\text { Changed }\end{array}$ & $\begin{array}{c}\text { Supply and Demand } \\
\text { Changed }\end{array}$ & $\begin{array}{c}\text { Savings due to } \\
\text { demand changes }\end{array}$ \\
\hline 5 & 0.1 & 1.7 & 1.5 \\
15 & 3 & 3.6 & 0.6 \\
20 & 6.8 & 4.3 & -2.5 \\
25 & 10.7 & 4.9 & -5.7 \\
40 & 11.7 & 9.7 & -2 \\
50 & 12.3 & 12.5 & 0.3 \\
55 & 12.4 & 17 & 4.6 \\
60 & 12.7 & 22.5 & 9.8 \\
70 & 16.6 & 32.7 & 16.1 \\
75 & 22.9 & 44.9 & 21.9 \\
\hline
\end{tabular}


To further examine the effect of demand we show the capacity and generation changes for the cases using $\$ 25 / \mathrm{tC}$ in Table 5 . When demand is allowed to change, total energy demand is reduced by $4 \%$, but the peak is reduced by $12 \%$. Consequently, no CC plants are built, and other technologies have their capacities reduced. However, with no baseload CC plants, coal generation increases $10 \%$.

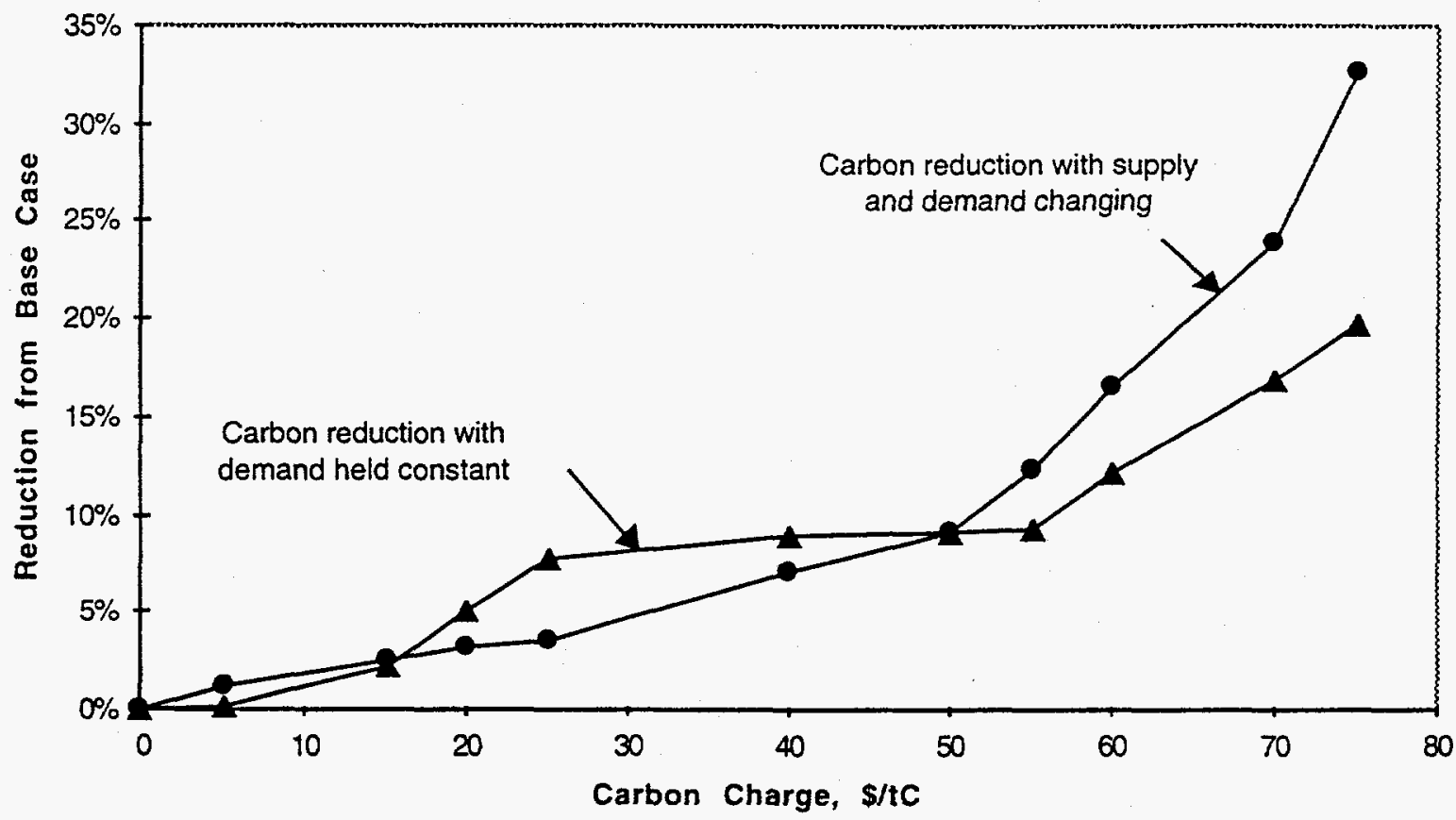

Figure 11. Higher carbon reduction at low carbon charges with demand held constant than if demand reduced due to price elasticity.

With the charge set at $\$ 40 / \mathrm{tC}$, CT plants become cost-effective replacements for some less efficient existing coal plants. Above $\$ 55 / \mathrm{tC} \mathrm{CC}$ plants start penetrating the market, displacing coal plants. At higher carbon charges, above $\$ 50 / \mathrm{tC}$, the demand reductions plus the new plants that displace coal plants give higher reductions than just changing the supply side alone. By $\$ 75 / \mathrm{tC}$, the effect of demand reductions about equals the effect of supply changes.

The capacity and generation mix by technology for the cases without demand reductions are shown in Figures 12 and 13. The overall capacity generation levels are the same in all cases, but the mix of sources changes. Figures 12 and 13 can be compared to Figures 8 and 9 , which show the capacity and generation mix with demand reduced. CC generation penetrates at much lower carbon charge rates in Figures 12 and 13, displacing coal and lowering carbon emissions. 
Table 5. Capacity and generation by technology for $\$ 25 / \mathrm{tC}$ charge cases, with and without elasticity effect.

\begin{tabular}{|c|c|c|c|c|}
\hline & $\begin{array}{c}\$ 25 \text { Charge } \\
\text { without Demand } \\
\text { Reduction }\end{array}$ & $\begin{array}{l}\text { \$25 Charge } \\
\text { with Demand } \\
\text { Reduction }\end{array}$ & Difference & $\begin{array}{c}\text { Percentage } \\
\text { Change }\end{array}$ \\
\hline Demand, MW-year & 66545 & 64213 & $-2,332$ & -4 \\
\hline Peak, MW & 104777 & 92220 & $-12,557$ & -12 \\
\hline Carbon emission, $\mathrm{MtC}$ & 126.3 & 132.2 & 6 & 5 \\
\hline \multicolumn{5}{|c|}{ Capacity, MW } \\
\hline Nuclear & 6,729 & 6,729 & 0 & 0 \\
\hline Coal & 83,353 & 82,084 & $-1,269$ & -2 \\
\hline Oil & 2,433 & 1,722 & -711 & -29 \\
\hline Gas-CT & 5,938 & 5,180 & -758 & -13 \\
\hline Gas-CC & 8,559 & 0 & $-8,559$ & -100 \\
\hline Gas-ST & 3,295 & 3,295 & 0 & 0 \\
\hline Hydro & 756 & 756 & 0 & 0 \\
\hline Total & 111,064 & 99,766 & $-11,298$ & -10 \\
\hline \multicolumn{5}{|c|}{ Generation, MW-year } \\
\hline Nuclear & 5,356 & 5,356 & 0 & 0 \\
\hline Coal & 52,925 & 58,076 & 5,151 & 10 \\
\hline Oil & 8 & 13 & 4 & 49 \\
\hline Gas-CT & 137 & 290 & 153 & 112 \\
\hline Gas-CC & 7,738 & 0 & $-7,738$ & -100 \\
\hline Gas-ST & 60 & 157 & 98 & 163 \\
\hline Hydro & 320 & 320 & 0 & 0 \\
\hline Total & 66,545 & 64,213 & $-2,332$ & -4 \\
\hline
\end{tabular}




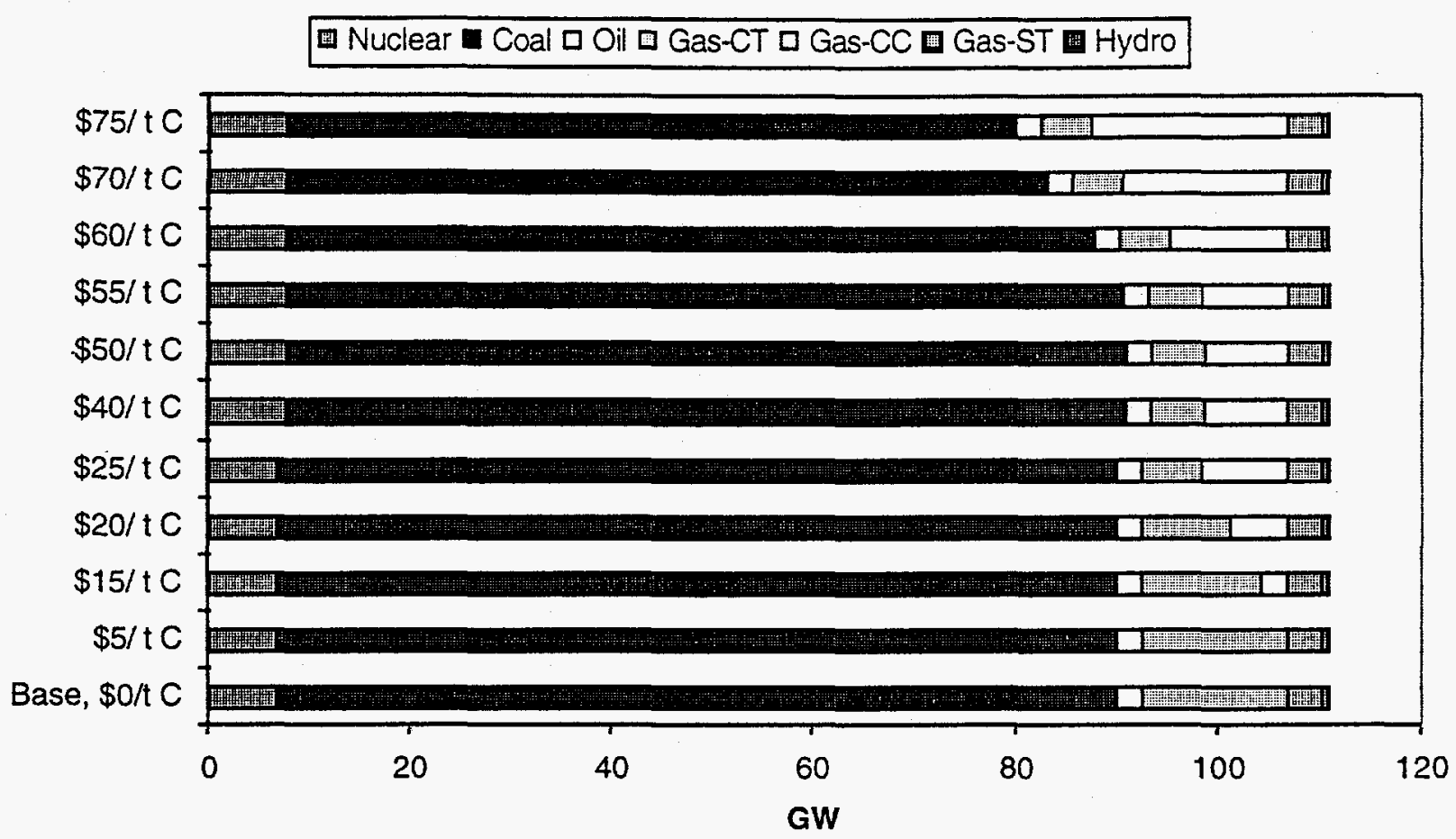

Figure 12. ECAR capacity (GW) with varying carbon charge rates and constant demands.

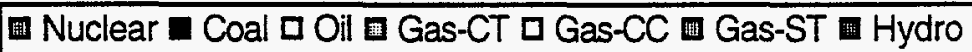

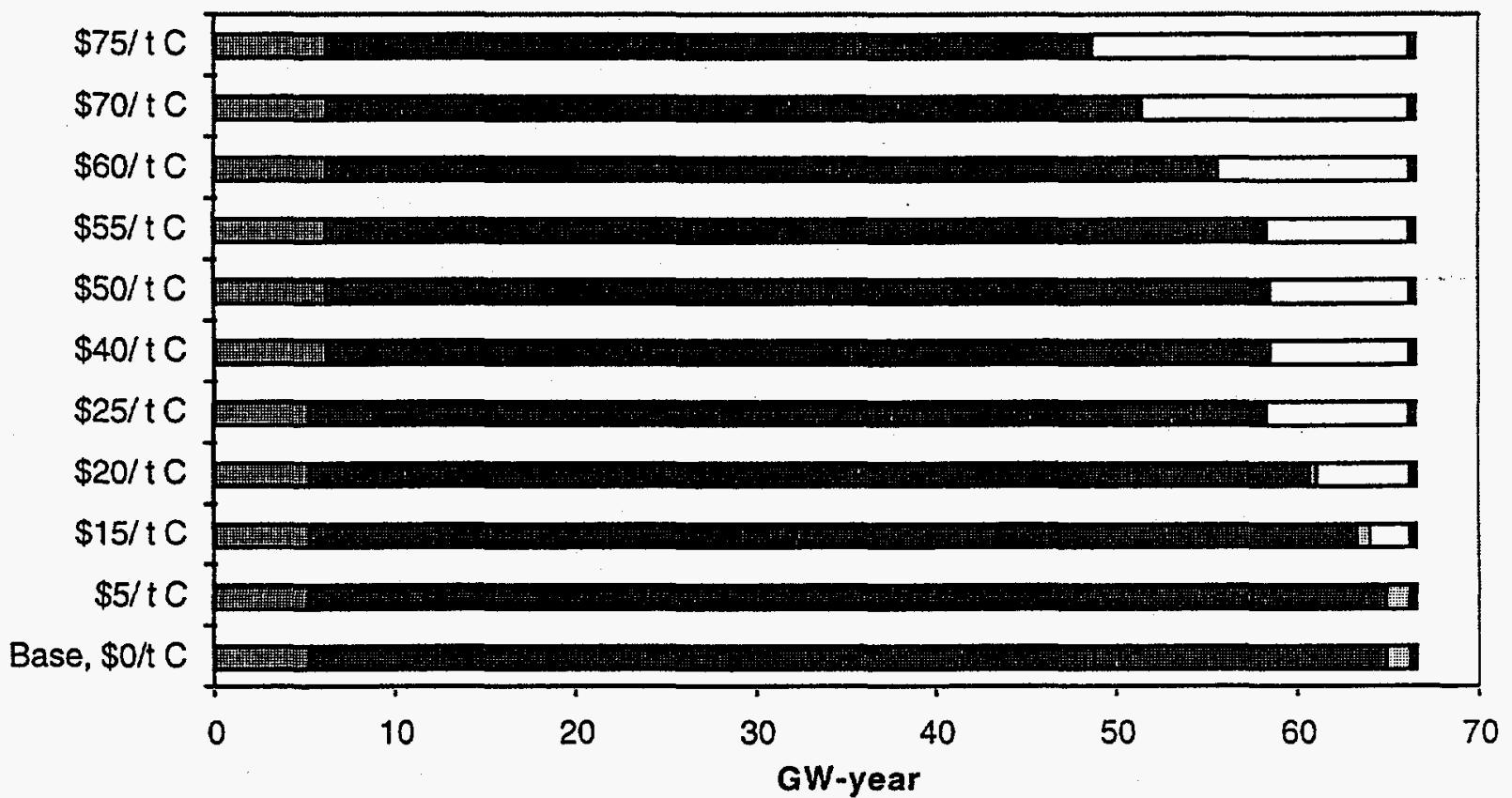

Figure 13. ECAR generation (GW-year) with varying carbon charge rates and constant demands. 


\section{OHIO-SPECIFIC RESULTS}

While much of this study has dealt with a consolidated ECAR region, specific results for Ohio utilities can be separated out. The initial set of plants scheduled for operation by 2010 gave Ohio a large excess capacity of $18.5 \%$, compared to the non-Ohio ECAR region with a figure of $-1.9 \%$. This implies a large amount of power exporting from Ohio to elsewhere under current plans.

When we optimize the base case for minimum avoidable cost but keep demand the same the reserve margin for Ohio drops to $6.4 \%$. The 1644-MW new coal plant, $2283 \mathrm{MW}$ in CC plants, and the Perry nuclear plant are not built or are retired. If peak demand drops due to elasticity, gas turbines scheduled beyond 2001 are canceled. Gas turbine capacity increases if demands are kept the same.

Perry's high fixed O\&M cost of $\$ 136 / \mathrm{kW}$-year makes it uneconomical, regardless of sunk capital cost. If the Perry operators reduce its O\&M costs, it may prove economical to continue. Also, if an emission charge of $\$ 55 / \mathrm{tC}$ or higher is applied, then the plant is kept online.

The first Ohio coal plant impacted by the rising caps or charges is the Mansfield plant located at Shippingport, Pennsylvania, and at least partially owned by Toledo Edison, Ohio Edison, and Cleveland Electric Illuminating. Its coal cost is $25 \%$ above the average for Ohio utilities and its fixed O\&M costs, at $\$ 32 / \mathrm{kW}$-year, are also high. It is shut down when carbon charges hit $\$ 50 / \mathrm{tC}$.

Electricity prices for Ohio track closely with prices for the whole ECAR region. Running both regions separately in the two-region version of ORCED, we find that the average market price for Ohio is within one mill/kWh in the various cases. Given the lack of transmission constraints within the region, this is understandable. 


\section{CONCLUSIONS}

Of the mechanisms proposed to reduce carbon emissions from the electric power sector, two important mechanisms are a cap on emissions or a tax on emissions. If trading of emission allowances is permitted, then their price affects the variable cost and the electricity price in a manner similar to that of a tax on carbon emissions. This holds true if prices are based on marginal costs, as in a competitive market, rather than average costs as in a regulated market. Economic efficiency, risk and uncertainty, and ultimate objectives will all play a role in establishing the mechanism for controls, if controls are established.

We created a set of cases to simulate the ECAR regional electricity market, with Ohio as a subset, for 2010 under different levels of carbon charges. Electricity demands were lowered based on the real-time prices that were calculated assuming no change in demand, and then the model was rerun with the new set of demands. Figure 14 shows the changes to key parameters with carbon charges set at $\$ 25 / \mathrm{tC}, \$ 50 / \mathrm{tC}$, and $\$ 75 / \mathrm{tC}$.

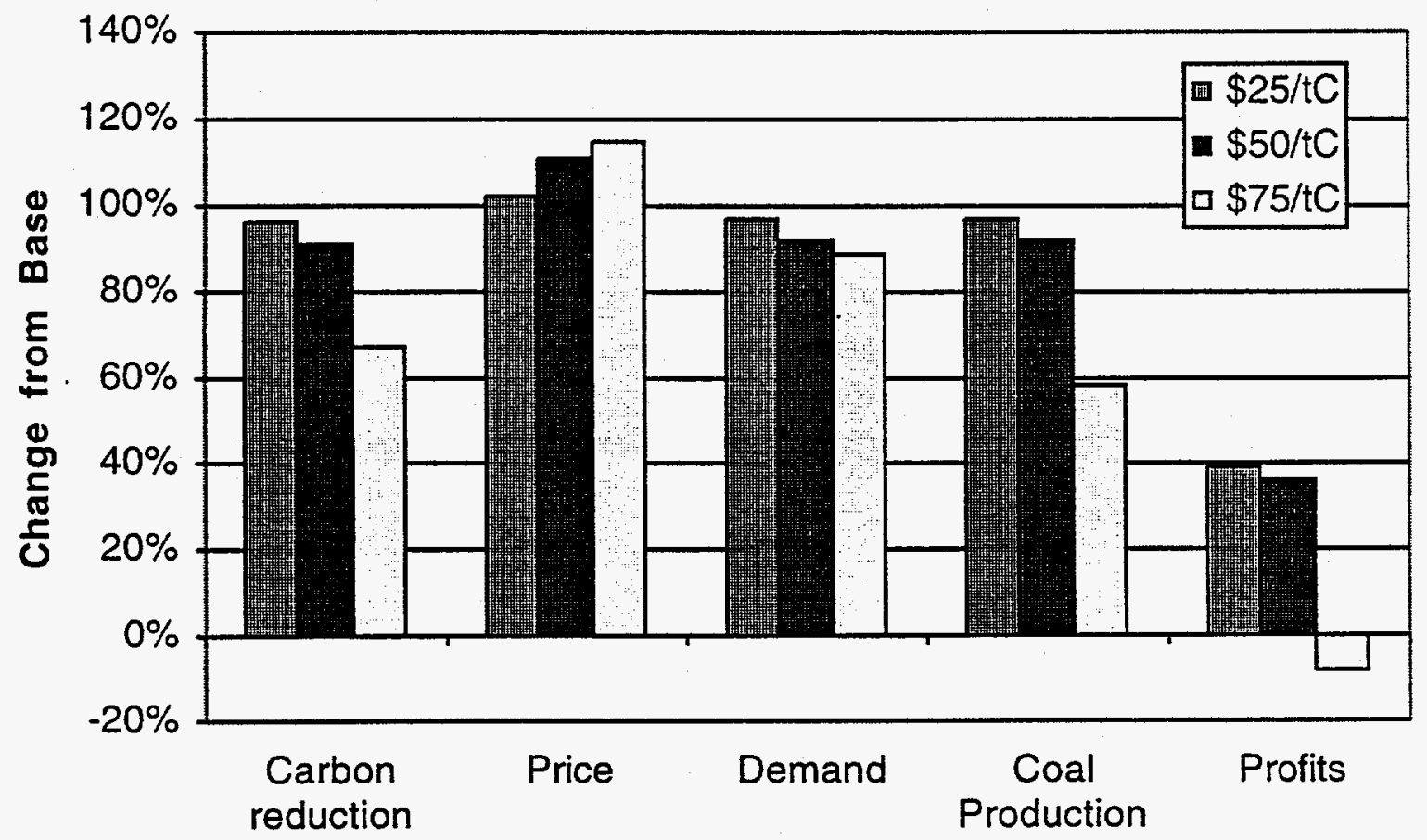

Figure 14. Changes in key parameters with carbon charges of $\$ 25 / \mathrm{tC}, \$ 50 / \mathrm{tC}$, and $\$ 75 /$ C. 
Our analysis indicates that significant reductions $(>10 \%)$ in carbon emissions for ECAR and Ohio will require carbon charges greater than $\$ 50 / \mathrm{tC}$. With no changes in consumer demand, savings are available at low carbon charges by building $\mathrm{CC}$ plants instead of $\mathrm{CT}$ plants. However, the peak demand reductions from real-time pricing in combination with carbon charges reduce or eliminate the need to build either type of plant, except for those already planned to meet nearterm demands. This conclusion, however, is predicated on the consumer response to real-time pricing. Further analysis is warranted on this issue because of its impact on our final results.

Once prices exceed around $\$ 50 / \mathrm{tC}$, the newer low-carbon technologies begin to displace existing coal capacity. At $\$ 75 / \mathrm{tC}$, many existing coal plants are still competitive with new technologies, but overall coal production is down significantly.

Generation prices increase from $3.0 \phi / \mathrm{kWh}$ in the base case to $3.9 \notin / \mathrm{kWh}$ with a carbon charge of $\$ 75 / \mathrm{tC}$. As a result of this increase (tempered by no change in nongeneration prices), total demand declines from $582,000 \mathrm{GWh}$ to $515,000 \mathrm{Gwh}$, an $11 \%$ decline. Peak demands decline from $95,000 \mathrm{MW}$ to $86,000 \mathrm{MW}$, a $10 \%$ decline. Even with no carbon charges, real-time pricing lowers the peak from an original estimate of $105,000 \mathrm{MW}$ while keeping overall energy demand approximately the same.

Profitability for generators declines with increased carbon charges. This is partly due to the reduced demand from higher prices, creating a larger reserve margin. The high peak prices that are a large source of the profits for plants in a marginal-cost based pricing system are not available as much of the time. Also, at higher carbon charge levels, new CC plants are built to displace less efficient coal plants. The capital costs of these plants are not reflected in their variable costs so are not as easily collected through marginal-cost pricing.

In the model, some specific plants are the first to be retired. Notably, the Perry nuclear plant is retired if there are no carbon charges because of its high O\&M costs. The Mansfield plant is one of the first Ohio coal plants retired as carbon charges increase. However, the data for all of the plants are based on operations between 1993 and 1995. Under competition, many plants will lower their O\&M costs, thereby changing the mix of plants that were modeled in this study. 


\section{ACKNOWLEDGMENTS}

I thank Jim Turnure, our U.S. Environmental Protection Agency program manager, for his support throughout this project. I thank Dan Johnson, Klaus Lambeck, and other staff in the Public Utility Commission of Ohio for their assistance and advice while I was developing the data and for reviewing the results of this project. Thanks go to Ken Rose, David South, Gale Boyd, David Schoeberlein, Dan Klein, and Greg McCall for their helpful comments on a draft of this report. I especially want to thank Eric Hirst for his advice, reviews, and encouragement in completing this paper. 



\section{REFERENCES}

EIA (Energy Information Administration) 1996a. Annual Energy Outlook 1997 with Projections to 2015, DOE/EIA-0383(97), U.S. Department of Energy, Washington, D.C.

EIA (Energy Information Administration) 1996b. Electric Generating Plant Data for 1995, $\mathrm{ftp} / / \mathrm{ftp}$.eia.doe.gov/pub/electricity/f86095.exe, U.S. Department of Energy, Washington, D.C., December.

EIA (Energy Information Administration) 1997. Electricity Prices in a Competitive Environment: Marginal Cost Pricing of Generation Services and Financial Status of Electric Utilities-A Preliminary Analysis Through 2015, DOE/EIA-0614, U.S. Department of Energy, Washington, D.C., August.

Faruqui, A., S. Shaffer, K. P. Seiden, S. Blanc, and J. H. Chamberlin 1991. Customer Response to Rate Options, EPRI CU-7131, prepared by Barakat \& Chamberlin, for the Electric Power Research Institute, Palo Alto, Calif., January.

Feyzioglu, Galip, ed. 1997a. Ohio Long-Term Forecast of Energy Requirements, 1995-2015, Division of Forecasting, Utilities Department, Public Utilities Commission of Ohio, Columbus, April.

Feyzioglu, Galip, ed. 1997b. Technical Appendix to Ohio Long-Term Forecast of Energy Requirements, 1995-2015, Division of Forecasting, Utilities Department, Public Utilities Commission of Ohio, Columbus, April.

Hadley, Stan, and Eric Hirst 1998. ORCED: A Model to Simulate the Operations and Costs of Bulk-Power Markets, ORNL/CON-464, Oak Ridge National Laboratory, Oak Ridge, Tenn., June.

Interlaboratory Working Group 1997. Scenarios of U.S. Carbon Reductions: Potential Impacts of Energy Technologies by 2010 and Beyond, co-published: LBNL-40533, Lawrence Berkeley National Laboratory, Berkeley, Calif.; ORNL/CON-444, Oak Ridge National Laboratory, Oak Ridge, Tenn., September.

Klein, Daniel E., Ira H. Shavel, David J. Doyle, and Jerry L. Golden 1993. "Carbon Taxes and Carbon Limits Are Not the Same," paper presented to the 15th Annual North American Conference, International Association for Energy Economics, Seattle, Wash., October. 
Lambeck, Klaus 1997. Data culled from the Long-Term Forecast Reports filed by Ohio utilities with the Public Utility Commission of Ohio, August.

Leary, N. A., and J. D. Scheraga 1994. "Policies for the Efficient Reduction of Carbon Dioxide Emissions," International Journal of Global Energy Issues 6, nos. 1/2:102-11.

RDI (Resource Data International) 1997. Powerdat Database, Resource Data International, Boulder, Colo.

Scheraga, Joel D., and Neal A. Leary 1992. "Improving the Efficiency of Policies to Reduce $\mathrm{CO}_{2}$ Emissions," Energy Policy 20, no. 5:394-404. 
1. L. Baxter

2. V. D. Baxter

3. L. Berry

4. D. J. Bjornstad

5. M. A. Brown

6. J. Christian

7. G. Courville

8. T. R. Curlee

9. P. D. Fairchild

10. S. Hadley

11. L. J. Hill

12. E. Hirst

13. P. J. Hughes

14. B. Kirby

15. R Lee
16. P. Leiby

17. J. M. MacDonald

18. V. C. Mei

19. D. E. Reichle

20. A. C. Schaffhauser

21. M. Schweitzer

22. R. B. Shelton

23. J. Tomlinson

24. B. E. Tonn

25. J. Van Dyke

26. J. VanCoevering

27. T. J. Wilbanks

28. Central Research Library

29. Document Reference Section

30. Laboratory Records (RC)

\section{EXTERNAL DISTRIBUTION}

31. Dr. Lilia A. Abron, President, PEER Consultants, P.C., 1000 N. Ashley Drive, Suite 312 , Tampa, FL 33602

32. Dr. Thomas E. Drabek, Professor, Department of Sociology, University of Denver, Denver, CO 80208-0209

33. Dr. Stephen G. Hildebrand, Director, Environmental Sciences Division, Oak Ridge National Laboratory, P.O. Box 2008, Oak Ridge, TN 37831-6037

34. Mr. P. Richard Rittelmann, FAIA, Executive Vice President, Burt Hill Kosar Rittlemann Associates, 400 Morgan Center, Butler, PA 16001-5977

35. Dr. Susan F. Tiemey, The Economic Resource Group, Inc., One Mifflin Place, Cambridge, MA 02138

36. Dr. C. Michael Walton, Ernest H. Cockrell Centennial Chair in Engineering and Chairman, Department of Civil Engineering, University of Texas at Austin, Austin, TX 78712-1076

37.-38. OSTI, U.S. Department of Energy, P.O. Box 62, Oak Ridge, TN 37831

39. Office of Assistant Manager for Energy Research and Development, DOE/ORO, P.O. Box 2001, Oak Ridge, TN 37831-8600

40.- $\quad$ External Electric Industry Policy Studies Group distribution mailing list and extra copies to E. M. Schorn, 4500N, H-19A 